OPEN ACCESS

Edited by:

Albie Miles,

University of Hawaii-West Oahu,

United States

Reviewed by:

Jan W. Low

International Potato Centre, Kenya

Niels Peter Louwaars,

Plantum NL, Netherlands

*Correspondence:

Teshome Hunduma Mulesa

teshome.mulesa@nmbu.no

orcid.org/0000-0002-1244-2629

Specialty section:

This article was submitted to

Climate-Smart Food Systems,

a section of the journa

Frontiers in Sustainable Food Systems

Received: 15 July 2021

Accepted: 07 October 2021

Published: 10 November 2021

Citation:

Mulesa TH (2021) Politics of Seed in Ethiopia's Agricultural Transformation:

Pathways to Seed System

Development.

Front. Sustain. Food Syst. 5:742001.

doi: 10.3389/fsufs.2021.742001

\section{Politics of Seed in Ethiopia's Agricultural Transformation: Pathways to Seed System Development}

\author{
Teshome Hunduma Mulesa*
}

Department of International Environment and Development Studies, Noragric, Nonwegian University of Life Sciences, Ås, Norway

Seed system development in the developing world, especially in Africa, has become a political space. This article analyzes current Ethiopian seed politics in light of the historical dynamics of national and international seed system politics and developments. Drawing on multiple power analysis approaches and employing the lens of "international seed regimes," the article characterizes the historical pattern of seed regimes in Ethiopia. While colonial territories underwent three historical seed regime patterns - the first colonial seed regime, the second post-WWII public seed regime, and the third post-1980s corporate-based neoliberal seed regime, Ethiopia has only experienced one of these. Until the 1950s, when the first US government's development assistance program - the Point 4 Program-enabled the second government-led seed regime to emerge, the farmers' seed systems remained the only seed innovation and supply system. The first colonial seed regime never took hold as the country remained uncolonized, and the government has hitherto resisted the third corporate-based neoliberal seed regime. In the current conjuncture in the contemporary Ethiopian seed regime, four different approaches to pluralistic seed system development are competing: (1) government-led formalization, (2) private-led formalization, (3) farmer-based localization, and (4) community-based integrative seed system developments. The Pluralistic Seed System Development Strategy (PSSDS) from 2013 is a uniquely diverse approach to seed system development internationally; however, it has yet to realize its equity and sustainability potential. This study shows that the agricultural modernization dependency and government-led formal seed systems development have sidelined opportunities to tap into the strength of other alternatives identified in the PSSDS. In conclusion, an integrative and inclusive seed sector is possible if the government takes leadership and removes the current political, organizational, and economic barriers for developing a truly pluralistic seed system.

Keywords: seed politics, seed regime, power analysis, pluralistic seed systems, 4D pathways approach, Ethiopia 


\section{INTRODUCTION}

Calls for zero hunger, poverty eradication, and adaptation to climate change have increased the focus on seeds and seed system development in sub-Saharan Africa. The focus has been explicitly geared toward developing and supplying good quality seeds of improved varieties among smallholder farmers aiming at agricultural production and productivity increase, nutritional enhancement, system resilience, and income generation (Otieno et al., 2017; Ariga et al., 2019). To contribute to these goals, donor countries, multilateral institutions, foundations, and non-governmental organizations (NGOs) have supported several policies and programs ${ }^{1}$ (Odame and Muange, 2011; Joughin, 2014; Borman et al., 2020; FAO, 2020). However, while most actors' policy and program interventions share the goal of increasing seed security among smallholder farmers, the strategies differ substantially and sometimes conflict (Scoones and Thompson, 2011; Westengen, 2017). These policy and program interventions also come with pressure from diverse actors who want their interests to be met with appropriate measures. Simultaneously, a country's political regime's governance and economic system want policies to align with its interests and priorities, making it difficult for policymakers and legislatures (Tansey, 2011; Mockshell and Birner, 2015). Moreover, actors' diverse interests and strategies contribute to the lack of coherent policies, programs, and practices to create a robust seed system development and enhance seed security (de Boef et al., 2010; Amanor, 2011).

This article is about seed system politics and development in Ethiopia. It aims to describe and analyze Ethiopia's seed system development trajectories under three different governance regimes and focuses on its current pluralistic seed system development strategy (PSSDS). It examines why and how the formal seed system has been prioritized over other alternatives (farmers' and community-based seed systems) by government policies and programs since the beginning of Ethiopia's agricultural modernization in the 1950s. It shows how the agricultural modernization agenda (Geels, 2004) ignores opportunities to tap into the strength of the farmers' seed systems (Mulesa et al., 2021), even after its official recognition by government policy in 2013 (MoA and ATA, 2017), and the experience of decades of an ineffective formal seed system (Ariga et al., 2019). The article further illustrates how developing countries' growing seed systems development debate generates challenges for policymakers and governments using the Ethiopian case. The discussions have put policymakers under financial and donor pressure to develop coherent national seed policies while at the same time serving the national governance regime's overall agricultural development plans.

\footnotetext{
${ }^{1}$ Some of the recent programs and policies related to seed sector development in Africa include: African Seed and Biotechnology Program (ASBP), Integrated Seed Sector Development (ISSD) program in Africa, Alliance for a Green Revolution (GR) in Africa's Program for Africa's Seed Systems (AGRA/PASS), World Bank's Seed Sector Development projects, COMESA Seed Harmonization Implementation Program (COMSHIP), ASARECA's Seed Policies and Regulations harmonization in East African Community, SADC Seed Laws harmonization program and ECOWAS's Harmonization of Seed Trade Laws in West Africa.
}

A seed system refers to physical, organizational, and institutional components, their actions and interactions that determine seed conservation, improvement, supply, and use (Cromwell, 1992; Scoones and Thompson, 2011), and includes formal, informal, and emerging "intermediate" seed systems (Mulesa et al., 2021). Farmers' seed systems involve farmers' seed selection, production, storage, and dissemination (Almekinders and Louwaars, 2002). The formal seed system comprises public and private sector institutions and a linear series of activities along the seed value chain, including germplasm conservation in genebanks, plant variety development, variety release and registration, quality seed production, and distribution (Louwaars et al., 2013). The intermediate seed system has recently emerged from market-oriented farmer groups that produce and market non-certified seeds of improved varieties and farmer-preferred local varieties. These are communitybased seed producer groups, including community seed banks that produce good quality uncertified seeds (MoA and ATA, 2017) and seed producer cooperatives (SPCs), who produce quality declared seeds of improved varieties (Kansiime and Mastenbroek, 2016; Sisay et al., 2017). Quality declared seed is a simplified certification scheme in which seed-producing farmers are responsible for seed quality while the government plays a monitoring role (FAO, 2006).

Until the advent of the first Green Revolution (GR), the ageold practice of seed saving, selection and exchange, and farmers' knowledge associated with seed use and seed sourcing were the single most important seed systems farmers used in Ethiopia. The 1960s and 1970s transfer of the technology paradigm during the first GR in Africa promoted formal seed systems to boost agricultural production and productivity (Groosman et al., 1991; Tansey, 2011; Byerlee, 2020). Since then, developing countries, including Ethiopia, have used the linear model of formal seed systems as a blueprint solution for seed sector development. This approach assumed that the farmers' seed systems would be replaced by the government-led formal seed system, gradually moving toward privatization and liberalizing the seed market with the public sector's withdrawal (Louwaars and de Boef, 2012; Louwaars et al., 2013). Despite these assumptions, the farmers' seed systems remain the leading supplier of large quantities of seeds of diverse crops and varieties in developing countries (Coomes et al., 2015; McGuire and Sperling, 2016). Over the years, critical voices have risen in response to the linear formal seed system's poor performance. Its perceived and actual consequences for seed security and seed governance issues are today a debated topic. Emanating from these debates are alternative development visions and pathways suggested by different actors. These alternative development visions include formalization vs. localization of seed systems, high-yielding improved varieties vs. locally adapted farmers' varieties, privateled vs. government-led certified seed supply, community-based vs. private-led seed production and marketing, and farmers' rights vs. plant breeders' rights.

This article's point of departure is that the seed is political. All areas of contestation (environmental, social, economic, political, and system resilience) around seeds involve asymmetric power (Tansey, 2011; Sumberg et al., 2019). For instance, studies 
show that intellectual property rights (IPRs) over seeds and seed regulations have resulted in seed market concentration in the hands of few multinational seed companies. Consequently, the socio-cultural connections between people and plants have mobilized resistance against IPRs and seed market concentration (Lyon et al., 2021; Tschersich, 2021). In this case, power asymmetry relates to access to and control over seeds. Moreover, studies suggest that particular historical factors shape national seed policies within each country (Westengen et al., 2019; Mulesa and Westengen, 2020). Therefore, contestation of seed system development pathways is ongoing in Africa as the production and regulation of seeds limit farmers' political and economic participation and weaken state political interests under the current "New Green Revolution" (Scoones and Thompson, 2011; Mayet, 2015).

Analyzing Ethiopia's historical seed sector development brings valuable knowledge to the seed systems literature. European countries never colonized Ethiopia, unlike many other countries in Africa. For this reason, its institutional foundation is independent of colonial influences. Ethiopia's long history of independence means that national autonomy is practiced in policy formulation (Keller, 1991). It has also undergone different governance regimes with different agricultural modernization approaches since the establishment of its Ministry of Agriculture (MoA) in 1907 (Diriba, 2018) and especially after its re-establishment following the second Italo-Ethiopian war (1936-41) in 1943 (Belay, 2003). Ethiopia's governance and economic systems changed from authoritarian monarchy rule/dominant feudal society (Cohen, 1974a) to military government/dominant socialist enterprises (Cohen and Isaksson, 1988) to an authoritarian developmental state/"free market” economy (Clapham, 2018). These governance regimes had different political effects on agricultural development that have affected the seed sector development pathways. Moreover, Ethiopia experienced extreme disasters such as drought, war, and consequent famine during the socialist regime, which created debate among technocrats about the role of formal and farmers' seed systems since the 1980s. Exploring seed sector development by considering these political and economic regime changes and environmental shocks provides unique perspectives to better understand how historical settings impact the dynamics of current seed system policy processes and practices.

In recent years, Ethiopia has gone "against the grain," deviating from the linear approach to formal seed system development by favoring a PSSDS as the country's overarching seed policy (MoA and ATA, 2017; Mulesa et al., 2021). The government of Ethiopia was the first country to officially adopt a PSSDS in 2017 as an alternative to the dominant linear formal seed system development to comprehensively transform its seed sector. The PSSDS proposes support for three major seed systems operating in the country (informal, formal, and intermediate) and promotes complementarity between the value chain components of each seed system. It assumes that the public, private, community, and NGO stakeholders take particular roles in dissimilar seed value chains and integrate activities along the seed value chain between the three seed systems. This article is a follow-up of an in-depth study that examined farmers' seed security as functions of seed systems in two districts of Central Ethiopia characterized by subsistence-oriented teff cultivation and commercially oriented wheat production and relates this to the country's PSSDS (Mulesa et al., 2021). Mulesa et al. (2021) find that the interventions prioritized in the PSSDS can address the widespread seed insecurity and seed system dysfunctions identified in the study districts. However, the implementation lags, particularly for the informal seed system, which is neglected by government programs despite its role in supplying large quantities of seeds and most of the crops and varieties farmers use. The study suggested further research that examines the complex interplay of factors to understand why the Ethiopian government has not fully implemented the PSSDS. Therefore, this article analyzes the effects of actors' seed politics on the opportunities and challenges in creating more equitable and sustainable seed systems in the new PSSDS-as a unique contribution to seed system literature. I draw on Leach et al.'s (2020) power analysis which combines plural approaches for studying food politics and development. The power analysis is used to understand the dynamics of Ethiopia's seed sector development process over the past seven decades, starting from the emergence of formal seed systems in the mid-1950s. The approach is used to analyze a continuous and dynamic process of institutional transformation co-shaped by a complex interaction of the regime's political and economic orientation, global seed-related frames and funding, and local environmental risks and explores how different pathways have emerged. To do this, I examine the history of the seed sector's evolution under agricultural policies of three different governance regimes: imperial, socialist military, and authoritarian developmentalist. The analysis helps to understand how the government prioritized some seed sector policies while excluding other policies under these political regimes and the policy directions, benefits, costs, and risks involved in these processes. Specifically, the article addresses the following research questions: (1) How have seed sector development policies been formulated and implemented, (2) How have different actors' interests influenced seed policy formulation and implementation, and (3) What are the sociopolitical and ecological outcomes of the current seed system policies and practices in the country?

\section{ANALYTICAL FRAMEWORK}

To understand seed system politics and development in Ethiopia, I draw on the analytical approach of Leach et al. (2020), combining plural approaches/concepts underpinned by broader theoretical traditions in power analysis. From Leach et al.'s (2020) list of approaches to power analysis in food politics and development, my analysis of Ethiopia's seed sector policy development and implementation is informed by approaches of food regimes (Harriet and Philip, 1989), food institutions (Clapp, 2012), food contentions and movements (Borras et al., 2008; Patel, 2009), food innovation systems (Scoones and Thompson, 2009; IPES-Food, 2016) and food discourses (Sumberg et al., 2012). I treat these approaches as nested or use their possible 
pairwise combinations to study seed system politics and development in Ethiopia.

First, I identify the seed regime pattern linked to historical and political changes over the past seven decades of agricultural modernization in Ethiopia. The seed regime typology proposed by Lyon et al. (2021) is an adaptation of the food regime framework (Harriet and Philip, 1989; Jakobsen, 2021). In Leach et al.'s (2020) power analysis, the strength of an actor, and consequently its capacity to control exists in historically shaped political, social, and value regimes, including relations between states and capital and their supporting ideologies. In Ethiopia, the seed system development has changed from a farmer-managed seed system to a government-led formal seed system to a pluralistic approach. The seed regime approach can reveal how these changes occurred, who has gained and who has lost, implicating various power relations between diverse actors. As part of this analysis, historicizing institutional development allows to examine how the prior history of conflict or cooperation, the incentives for actors to participate, power and resource imbalances, governance and institutional design, shared narratives, interests, and politics have shaped the Ethiopian seed system development (McCann, 2005; Mulesa and Westengen, 2020).

Lyon et al. (2021) identify three seed regimes based on Kuyek's (2007) adaptation of Harriet and Philip's (1989) food regimes. The chronicles of these different seed regimes can vary from country to country, and not all countries have gone through the three seed regimes. The first seed regime is a relatively stable set of relationships, norms, and regulations that organized the increasing commodification and enclosure of seed during the early colonial period. Lyon et al. (2021) exemplify the first seed regime by describing the disruption of agricultural practices and foodways during the early colonial period when European settlers introduced few cash and commodity crops for the export market in North America. This regime constitutes colonial dispossession and displacement of indigenous people and their crop diversity. Post-WWII, the breeding, delivery, and adoption of new plant varieties by public institutions were the key features of the second seed regime. The third corporate-based neoliberal seed regime is related to the advent of transgenics in the 1980s (James and Krattiger, 1996) that enabled agrochemical firms to research and develop transgenic plants (Lyon et al., 2021) and prevent other actors from commercial production and marketing of their product using technological and legal control means (Tansey, 2011). Such technical and legal control of seeds was not new as this has been the practice since the 1930s in North America when hybrid cultivars emerged. However, IPRs protection ${ }^{2}$ of

\footnotetext{
${ }^{2}$ IPR protection of new cultivars started when the government of the United States (US) introduced Plant Patent Act in 1930, which allowed patenting of asexually reproducing plant cultivars (except tubers). In 1970, the US introduced the Plant Variety Protection (PVP) Act to protect new varieties of sexually reproducing crops. In Europe, the Netherlands (1942) and Germany (1953) were the first countries to introduce the PVP Act. The harmonization of the PVP Act started in 1957 through the facilitation of the Government of France. Later the European governments adopted the international system of protection of new plant varieties under the auspices of the International Union for the Protection of New Varieties of Plants (UPOV) Convention in 1961 (Correa, 2015). Since 1961, the UPOV
}

new cultivars became a global phenomenon with the advent of biotechnology applications to agriculture during the past five decades (Kloppenburg, 2004; Lyon et al., 2021). The IPR protection has given more power to the private sector in the seed industry to make independent decisions on what to invest in and the type of technology they can promote (Kuyek, 2007; Clapp, 2021). Government intervention is limited to facilitation, i.e., providing incentives and removing impediments for private sector investment. The overview of the history of seed sector development in Ethiopia shows a unique national pattern of seed regimes. As mentioned, Ethiopia never became a colony in the classical sense. Therefore, the first colonial seed regime never really took hold in Ethiopia. But post-WWII, we see a distinct patterning of seed regimes that follow other essential patterns in Ethiopian history. My analysis operates with three regimes at both levels, i.e., three governance regimes (imperial, socialist, and developmental government regimes), and uses three seed regime patterns (the first, second, and third seed regimes). However, the seed regimes do not follow the political regimes in a one-toone fashion.

I use the food institution approach to Leach et al.'s (2020) power analysis, which conceptualizes the actor's strength and capacity to control events as embedded in and to operate through multilevel formal and informal institutional arrangements, or the "rules of the game" (North, 1990). This kind of power contributes to the change in the food/seed system via norm and rule changes. Such norm and rule changes can occur in particular institutions or shifts in different institutions' relative power and influence (Tansey, 2011; Leach et al., 2020). The food institution approach provides a more nuanced picture of seed system development linked to smallholder agricultural commercialization. For instance, the food institution concept helps analyze Ethiopia's seed system development policy related to seed sector liberalization and privatization, funding requirements, and the government's political and economic orientation or national interests. In addition to incentives for the private sector, such liberalization can include the actual implementation of IPR laws and regional seed trade regulations. The food institution is associated with the food/seed contentions and movements approach, which involve power and agency that resist institutional changes through grassroots social mobilization and collective action, countering dominant force and interests (Demeulenaere and Piersante, 2020). This article applies the seed contention and movements approach to reveal how several years of joint project implementation and documentation work among NGOs (local and international) and a national institution influenced the government to recognize farmers' seed systems in Ethiopia.

While not restricting specific themes and contexts, I use the approaches of food innovation systems to analyze actors'

Act was amended a couple of times (1972, 1978, and 1991). National PVP Acts have been primarily developed based on the UPOV system to support the 1995 Trade-Related Aspects of Intellectual Property Rights (TRIPS) agreement of the World Trade Organization (WTO). Patents on plant traits (not varieties) emerged together with transgenics. In the Global South, stringent IPR protection (UPOV 1991 and plant patents) on seeds expanded since the adoption of TRIPS (Tripp et al., 2007). 
narratives, beliefs, values, practices, and rules for analyzing multiple trajectories of seed system development. Specifically, food/seed innovation systems emphasize socio-technical and ecological systems and their dynamic and complex interactions that involve different actors or institutions that challenge path dependencies or "lock-ins." The food innovation system approach can also explain the path dependency of promoting the dominant seed system development model as an intertwining political interest of the state. Finally, power and agency are located more firmly in ideas, rather than people, institutions, or systems in food discourses that can help understand the narratives, interests, politics, and actions of actors or narrative coalitions in seed system development. Overall, Leach et al. (2020) argue that the combination of different conceptualizations and power sites helps understand change and transformation owing to their relevance to a diversity of actors and relationships and various scales-at the local, national, and global level.

Concluding the historical pathway analysis, I engage the " $4 \mathrm{D}$ pathways approach" questions proposed by Leach et al. (2020) as an integrative analytical lens for assessing agri-food system political outcomes. Critical questions about the overall direction and diversity of technical and institutional innovation pathways, their distributional consequences, and the extent of democratic inclusion in decisions about the turning point in Ethiopia's seed policy reveal that the agricultural modernization dependency ignores opportunities to tap into the strength of the farmers' seed systems, even after their official recognition by the PSSDS in 2013 and after decades of an ineffective formal seed system.

\section{METHODS}

This study is a follow-up to a thorough investigation of the performances of different seed systems in two districts in the central highlands of Ethiopia, as mentioned in the introduction section. In order to address the above analytical questions and the main research questions, I gathered additional data using qualitative interviews with key actors in the seed sector during fieldwork in Ethiopia from December 2017 to March 2018. I interviewed 26 representative experts and researchers from various public and private institutions in agricultural and environmental governance. The actors include individual representatives from public seed enterprises $(N=5)$, private seed companies $(N=2)$, decision making and regulatory bodies $(N=6)$, NGOs $(N=5)$, agro-dealers $(N=4)$, and extension service providers $(N=4)$. The interview with each interviewee lasted between one and a half hours to $2 \mathrm{~h}$. Issues related to the genetic resource governance of plants and the supply and use of commercial seeds in Ethiopia are filled with asymmetric power relations, contestation, and seed struggle (Alemu, 2011; Mulesa and Westengen, 2020). With this in mind, I purposively selected the interviewees from actors with different politics and values, framings, and perspectives regarding agroecological, social, cultural, and economic factors. In addition to key informant interviews, the qualitative analysis utilizes participant observations in two national seed policy meetings. The first meeting was a 1-day "Workshop on Assessment and
Identification of Constraints to Private Seed Sector Development in Ethiopia" in February 2018. It gathered 40 representatives of key private and public seed sector actors. The second meeting was a 1-day "National Seed Policy Consultation Workshop" that gathered 63 representatives of seed sector actors from federal and regional institutions, farmers, NGOs, and the private sector in March 2018. I produced minutes from both meetings that documented actors' interests, politics, vision, activities in the seed system development from the presentations and discussions. I used this information to examine actors' approaches to Ethiopia's seed system development. In addition, the qualitative analysis of literature and documents uses a large volume of peerreviewed articles, research reports, policy and strategy documents in Amharic and English, and gray literature such as minutes from a high-level policy meeting. Information gathered from key informant interviews was triangulated with the document analysis to validate and supplement evidence to increase the validity of the findings.

\section{EARLY POLICY CHANGES: FROM FARMERS' CUSTOMARY SEED SYSTEMS TO GOVERNMENT-LED FORMAL SEED SYSTEM (THE EARLY 1900s TO 1974)}

\section{Bypassed Colonial Seed Regime}

The current diversity of seed systems in Ethiopia is the result of five to seven millennia of wild plant species domestication by indigenous people (Vavilov, 1992), selection and diversification of the domesticated species (Harlan, 1969), and seed exchange over a wide geographical range (Murdock, 1960; Harlan and de Wet, 1976). This age-old practice of seed selection, saving and exchange, and farmers' knowledge associated with seed use and seed sourcing (McGuire, 2007) are the foundations of the farmers' seed systems in Ethiopia (Thijssen et al., 2008). However, the diversification of farmers' seed source and management started to change in colonial countries of the developing world in the early 1900s. Europeans introduced new agricultural technologies (e.g., improved seeds) and technical agronomic practices to promote cash and commodity crops (Bonneuil, 2000; Austin, 2009). The colonial promotion of cash and commodity crops (e.g., coffee, cotton, and tea) brought a new set of relationships, norms, and control, which pushed out most indigenous crops such as sorghum and millet through agricultural extension and marketing (Tansey, 2011; Bezner Kerr, 2013). Scholars have seen the contours of a distinct colonial food/seed regime within this historical context (Kuyek, 2007; Lyon et al., 2021). For instance, the radical dispossession of indigenous crops in colonial Africa marks the first seed regime. Until their independence, imported crops displaced over 2000 native grains, fruits, vegetables, and root crop species in colonial Africa (National Research Council, 1996). National and international agricultural initiatives have also neglected these crop species, and these countries have been unable to repossess most of their food culture (Highfield, 2017, p. 3).

Unlike colonial African countries, Ethiopia did not go through the first seed regime. The imperial governments 
and Ethiopian people resisted Italian occupation and stayed uncolonized (Rubenson, 1961), and farmers continued to depend on their indigenous seeds and Neolithic agricultural innovations (Westphal, 1975; Diriba, 2018). The only exception was the introduction of agricultural technologies during their first Italian colonization attempt in the late nineteenth century and WWII, which discontinued owing to the first (18931896) and second (1935-41) Italo-Ethiopian war (McCann, 1995, 2011). Thus, farmers' seed systems remained the only supplier of seeds in Ethiopia until post-WWII. Ethiopia's seed regime change started with the second public seed research and development when the Imperial Ethiopian Government (IEG) introduced modern agricultural technologies. These included a mix of cash and commodity crops such as cotton and tobacco and the GR food crops (e.g., wheat and maize) discussed below.

\section{The Beginning of the Second Seed Regime During the Imperial Period in the 1950s}

Post-WWII, the advance in plant breeding in developed countries brought different technologies (e.g., new varieties) and seed management practices and created formal institutions to govern breeding, delivery, and adoption of new plant varieties (Timothy et al., 1988; Fernandez-Cornejo, 2004). These new technologies and seed regulation practices through formal institutions were transferred to colonial countries in Africa in the 1920s except in Ethiopia (Rusike, 1995; Rusike and Donovan, 1996). In Ethiopia, this was delayed until the mid1950s (Simane, 2008), when the IEG established physical, organizational, and institutional infrastructure for agricultural research and extension. The IEG received financial support from the first United States (US) government development cooperation in the Global South and other multilateral donors for building institutional and physical infrastructure to achieve its ambition of a monetized economy (Elliott, 1957; McVety, 2012). In his inaugural speech in 1949, the incumbent President of the US, Harry S. Truman, announced his government's readiness to support agricultural modernization to fight hunger and poverty in developing countries (Truman, 1949). Scholars argue that Truman's speech marks the origin of modernization theory in development studies (Westengen and Banik, 2016). Following Truman's announcement, the US government established a development assistance program, widely known as the Point 4 Program $^{3}$, referring to President Truman's fourth point in his list of foreign policy objectives. At the time, Ethiopia was in a deep agricultural and food crisis after the second Italo-Ethiopian war

\footnotetext{
${ }^{3}$ President Harry Truman announced four major courses of action for achieving global peace and freedom post-WWII. Truman said, we will continue to (1) support the United Nations and related agencies, (2) American programs for world economic recovery, including reducing the barriers to world trade and increasing its volume, (3) strengthen freedom-loving nations against the dangers of aggression, i.e., in the form of collective defense arrangement within the terms of the United Nations Charter, and (4) embark on a bold new program for making the benefits of American scientific advances and industrial progress available for the improvement and growth of underdeveloped areas because more than half the people of the world are living in conditions approaching misery, their food is inadequate, and their economic life is primitive and stagnant.
}

(Diriba, 2018), and Emperor Haile Selassie sought US support while subscribing to their anti-communist stand (Velissariou, 1954; McVety, 2008). The US development partners used this as a reason to select Ethiopia in Africa's horn as a testing ground for Point 4 Program implementation (1952-1957) and to induce social and economic change through technology and capital transfer, assuming that this would eventually steer Ethiopia away from communism (McVety, 2012). The US government provided an average of USD 2,466,700 per year for economic and military assistance to the IEG between 1952 and 1957 (Elliott, 1957; McVety, 2012).

The Point 4 Program supported extensive infrastructure development, including establishing higher learning agricultural institutions, public and agriculture schools, community/agricultural clubs, and creating agriculture extension groups and training professionals. Besides, the IEG received financial and technical assistance from the United Nations Development Program and the Food and Agriculture Organization of the United Nations (FAO) to build the technical and institutional capacity for its agricultural research, extension, and technology dissemination. With this assistance, the IEG established the Ethiopian Institute of Agricultural Research (EIAR) and a seed unit at the MoA in 1966 (Stommes and Sisaye, 1979a; Bishaw and Louwaars, 2012). The physical and institutional infrastructure building laid a foundation for the IEG's agricultural modernization projects through public agricultural research and GR technology extension, which marks the main features of the second seed regime in Ethiopia. Ethiopia attempted to implement the first GR projects with this institutional base as part of the IEG's three successive five-year agricultural development plans from 1957 to 1973 (Cohen, 1975; Stommes and Sisaye, 1979a,b). Considering the seed regime pattern in Ethiopia, the second public seed regime found fertile ground owing to the emperor's shared anti-communism platform with the US administration. Ethiopia's seed policy moved from almost non-participation in the first colonial seed regime to becoming the "pioneer" of the second public seed regime in the horn of Africa. In addition to the 15 years of agricultural development plans, the IEG also prioritized commercialization concession contracts for foreign companies and established state commercial farms to produce export crops such as coffee, sugarcane, cotton, tobacco, fruits, and vegetables. For this purpose, the government appropriated land for investors, which displaced pastoralists, agro-pastoralists, and peasants from their grazing- and farmlands and their indigenous seeds. By examining the situation using the food institutions approach, we see the institutional and political factors were the leading causes of social exclusion and increased vulnerabilities. For instance, pastoralists and peasants became laborers and survived on a "contribution" rather than a wage payment. At the expense of this exploitation, the companies who exported agricultural products and the industrialists in Europe who exported machinery and technology were winners. In contrast, the IEG, whose benefit from taxes and dividends was lower than commodity import expenses, and laborers who squandered their local livelihoods, were losers (Bondestam, 1974). 
Later during the 1960s and early 1970s, the IEG's agricultural development plan emphasized the implementation of big GR projects. The biggest of all was the Chillalo Agricultural Development Unit in Ethiopia's southeastern highland supported by the Swedish International Development Cooperation Agency, which aimed to replicate a "successful" GR experience from the Comilla district of Bangladesh in 1957 (Karim, 1985). The agency's support focused on increasing bread wheat production and productivity using improved seeds, chemical fertilizer, and pesticides. The IEG later scaled out the GR projects to other regions in Ethiopia and crops (e.g., maize) with the financial and technical support from other donors such as the World Bank, United States Agency for International Development (USAID), and France's government (Cohen, 1974b; Stommes and Sisaye, 1979a). The IEG's first GR projects prompted seed system formalization. However, with its emphasis on donor-supported government agricultural research and extension for higher yields and productivity, the IEG's second seed regime of the GR projects created winners and losers among participants. Specifically, the political economy of the donor-supported and IEG-centered GR projects created inequality between landlords and tenants through its exploitative land tenure system, especially in the southern provinces of Ethiopia.

In the nineteenth and twentieth centuries, the "land hunger" of the imperial regime led to the expansion and consolidation of the southern regions by confiscating land from southerners and granting it to the regime's supporters from the north and center (Brietzke, 1976; Clapham, 2019). The imperial regime created solid political bondage with the few landlords and absentee landlords ${ }^{4}$, who acquired large tracts of fertile land. When they lost their land, most local tillers and pastoralists became peasants and tenant sharecroppers for the landlords. They paid one-third or one-half of their annual produce, depending on the fertility/productivity of the land they plowed. With the donor-supported GR projects, peasant sharecroppers became more vulnerable instead of benefiting from commercial wheat and maize production. For instance, corrupt local and provincial government officials and their associates neglected donor policy provisions to only supply subsidized inputs to peasants holding $<20$ hectares of land. Instead, they took advantage of their position and purchased the subsidized inputs under favorable credit terms (Cohen, 1975; Brietzke, 1976). In the rare cases where tenants had access to limited GR technologies, they benefited from yield increase as sharecroppers. Still, their landlords, who owned the land, benefited the most from the tenants' payment. Landlords also evicted their tenants when they saw the benefits of using GR packages compared to sharecropping. For each new machine these landlords acquired to expand their commercial farms, they evicted about 20 sharecropper tenant families (Bondestam, 1974; Cohen, 1975). According to Cohen (1975), GR seeds' arrival led to the eviction of about $20-25 \%$ of 60,000 tenant

\footnotetext{
${ }^{4}$ The landlords were members of the royal family, church, and high ranking clergymen, and absentee landlords were war returnees, senior military, and civil servants.
}

households between 1968 and 1971. Here, the agricultural modernization discourse of Truman and other donors which adhered to the preconceived belief in technological solutions to hunger and poverty failed to recognize the underlying structural problems, primarily the exploitative land tenure system of the IEG and poor physical and institutional infrastructure (e.g., roads, irrigation), diversity of crops and agro-ecology in Ethiopia.

Moreover, the adoption of high-yielding bread wheat and hybrid maize varieties resulted in local genetic erosion of farmers' seeds (e.g., barley, durum wheat, and local maize). Loss of local seeds and positive yield advantage created a dependency on commercial seed producers for new seeds and varieties, which were not always readily available (Teklu and Hammer, 2006). Overall, the IEG's GR projects contributed to inequality, creating elite winner landlords and hungry loser tenants and consumers (Ståhl, 1973), triggering the early 1970s riots among students, teachers, and the working middle class. When examined closely by drawing on approaches to food contentions and movements, these riots articulated frustration about hunger and famine created by the exploitative land tenure system and modern agricultural input supply of the IEG that favored the regime's loyalists. The riots amplified into a revolution popularly known with the slogan "Land to the Tiller," leading to Emperor Haile Selassie's overthrow by the socialist government in 1974 (Crewett et al., 2008; Yemane-ab, 2016).

\section{FOOD AND AGRICULTURAL CRISIS-INDUCED ALTERNATIVE SEED SYSTEM AND LOCK-INS IN THE GOVERNMENT-LED FORMAL SEED SYSTEM (1975 TO MID-2000s)}

\section{The Beginning of Seed Contestations and Movements in the Socialist Era in the Mid-1980s}

The mid-1970s witnessed landmark reforms to eliminate the feudal order in Ethiopia. The Military Administrative Council (PMAC) - also called Derg-announced that it would eradicate the imperial regime's traditions of autocracy, inequality, and subjugation as soon as it assumed power in 1974 (Harbeson, 1977). Not knowing what political ideology and economic system the PMAC would follow, the US government, World Bank, United Nations Development Program, and several bilateral and multilateral development cooperations continued to provide financial assistance to keep the GR project going. The donors also wanted to keep the new government from getting too friendly with the Soviet Union. The US government supplied about USD 250 million in economic and military aid to the PMAC until it halted following the PMAC's inauguration of a National Democratic Revolutionary Program in April 1976. With this program, the PMAC declared a return to civilian democratic government, but it announced its firm position to fight feudalism, imperialism, 


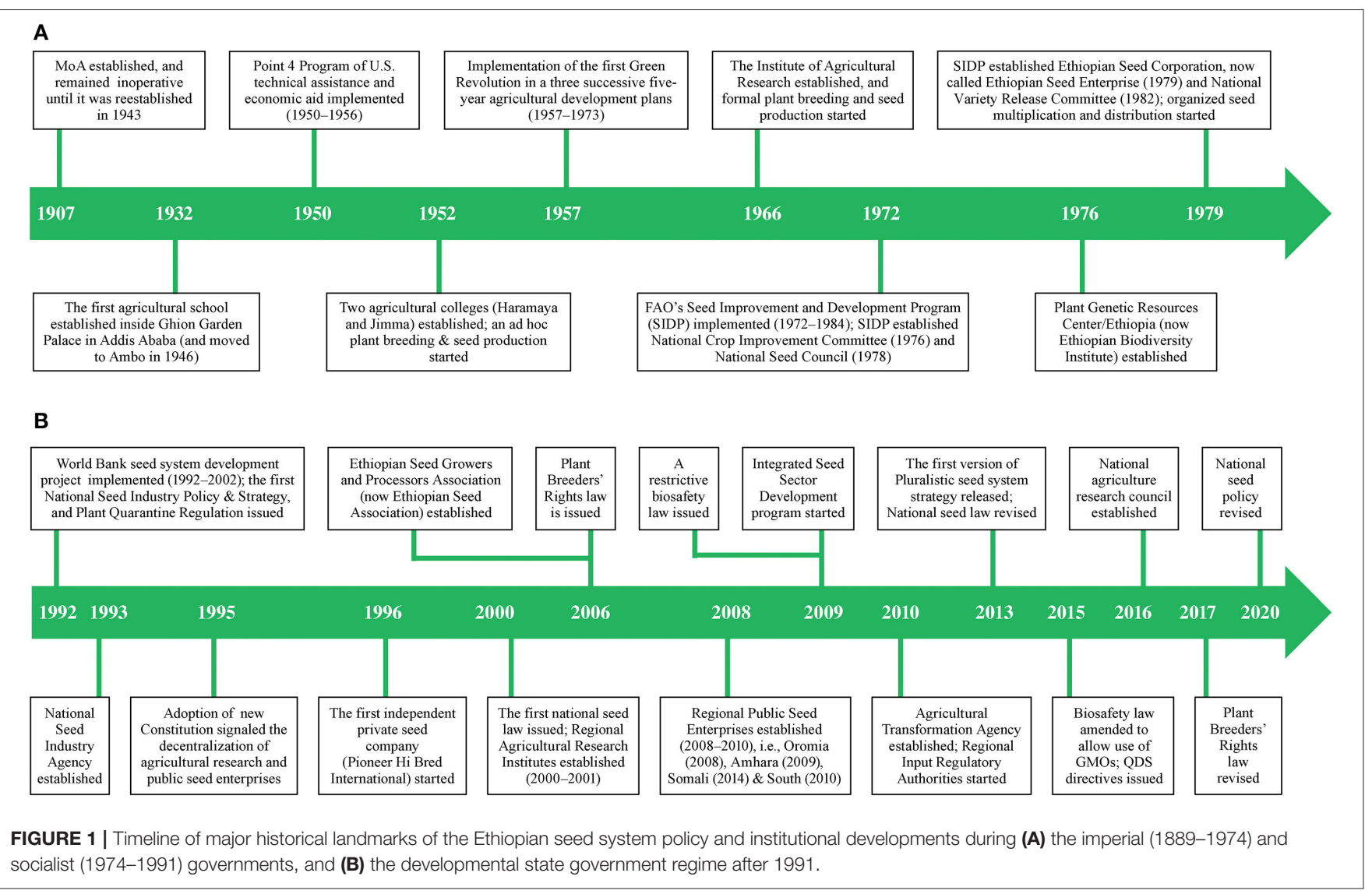

and capitalism and Ethiopia's transition to socialism (McVety, 2012).

The World Bank and other donors continued to support FAO's Seed Improvement and Development Program (SIDP), which started in 1972 in Ethiopia since the agriculture crisis was evident and hunger was looming at the time (Ker, 1979). The SIDP was implemented in many developing countries and aimed to develop the national capacity to multiply good quality seeds of high-yielding improved varieties, distribute them to farmers, increase production and productivity, and contribute to national and global food security (World Bank, 1980; FAO, 1984). In Ethiopia, the SIDP was probably the most notable second seed regime activity or public investment in crop improvement research and extension during the socialist government, mainly because of the limited funding from western development partners and political crises. The SIDP helped to establish Ethiopia's central institutions for the formal seed system between 1972 and 1984 (Figure 1A). Besides, it strengthened the EIAR's capacity in plant breeding and quality seed production by training plant breeders and agronomists. The EIAR conducted a plant breeding and adaptation trial of improved varieties introduced from Kenya, Mexico, Ecuador, and the US in partnership with the International Maize and Wheat Improvement Center and released 22 improved wheat varieties: 18 bread wheat and four durum wheat (Ker, 1979; Woldemariam, 1990). Although the SIDP contributed to the organizational development of the formal seed system, it did not develop a seed policy and regulatory framework in Ethiopia, unlike in other developing countries. Like in many developing countries, where it was implemented, SIDP also failed to create financial sustainability for the maintenance of the infrastructure and technical activities (e.g., seed laboratories, field inspection capabilities) in Ethiopia, which weakened the formal seed sector in the years that followed (Woldemariam, 1990; Cromwell et al., 1992).

That said, the socialist government introduced a radical land policy reform that abolished the feudalistic land tenure system by declaring all rural lands the collective property of the Ethiopian people and redistributed land to peasants previously held by landlords (PMAC, 1975). Moreover, the regime introduced an agricultural socialization policy that emphasized expanding state farms and cooperative farming through villagization, allegedly intending to increase crop production and productivity and eradicate famine in Ethiopia. However, although the land redistribution and cooperative expansion had increased the demand for improved seeds and chemical fertilizer, the government-led agricultural socialization, and subsidy on GR inputs failed to increase agricultural production and productivity. Both state and cooperative farms recorded the lowest yield (only 6\% of the national output) between 1975/76 and 1985/86, resulting in an estimated grain deficit between 350,000 and 500,000 metric 
tons despite the government's highest investment in these farms (Ghose, 1985; Cohen and Isaksson, 1988). The failure was due to a range of interlinked factors such as bureaucrats' lack of experience in mechanized farming, poor planning, inadequate input supply, mismanagement, discrimination of private peasants for input supply, and discouraging abusive peasant labor deployment (Ghose, 1985; Clapham, 1988). The overall consequence was low agricultural growth and a food crisis (Belete et al., 1991). Ultimately, the food and agriculture crises signaled the failure of modernization driven by agricultural socialization.

The combination of poor governance, civil war, and droughts of the mid-1980s and the resulting food and agriculture crisis (Keller, 1992) led to a new wave of seed contestation and movements (Cromwell et al., 1993). A coalition of environmentalists and local NGOs from Ethiopia joined an international movement advocating for on-farm management, facilitated access, and fair and equitable sharing of benefits from the use of plant genetic resources for food and agriculture (PGRFA)-hereafter referred to as the PGRFA movement (Pistorius, 1997). This coalition also advocated for strong farmer' seed systems in developing countries (Cooper et al., 1992). In Ethiopia, the major actor in the PGRFA movement was the Plant Genetic Resource Center/Ethiopia, now called the Ethiopian Biodiversity Institute (EBI). While actively participating in the international PGRFA movement that advocated for farmers' rights as a countermeasure to stringent IPRs (Pistorius, 1997), EBI worked to link farmers with genebanks through farmerbased PGRFA management projects since 1989 (Worede, 1992; Cromwell et al., 1993). As the PGRFA movement gained momentum in the 1980s and 90s, environmental sustainability discourses gradually pervaded science and technology. The Ethiopian PGRFA movement's discourse was that GR crops could not substitute Ethiopia's biodiversity treasure trove and did not consider the socio-cultural and agro-ecological diversity of the country linked to these resources. Proponents of the PGRFA movement argued that ensuring national food security and sustaining Ethiopian food culture requires promoting locally adapted diverse seeds and protecting valuable crop diversity (Worede, 1992). Their discourse attempted to frame locally adapted seeds as an alternative to GR varieties for Ethiopia's food and agricultural crisis. The discourse builds on the idea that local crop diversity is vital in providing yield stability and harvest security in the face of pests, diseases, and unfavorable environments (Clawson, 1985; Brush, 1992). Although this seed discourse did not yield a significant seed policy shift until 2013, it received recognition from the government and donors. Besides, it attracted several donors who supported projects for on-farm management of PGRFA and strengthened farmers' seed systems (Brink, 2013; Mulesa and Westengen, 2020). EBI and its collaborating local partners implemented several projects with the recognition of the MoA despite government emphasis on the use of GR technologies for agricultural development. From the late 1980s, EBI deployed local crop varieties from the national genebank to farmers' fields through a network of farmers and community seed banks in drought- and famine-affected areas and in the productive regions where GR modern varieties replaced local ones (Westengen et al., 2018).

\section{The Developmental State's Resistance to Seed Sector Liberalization Since the Early 1990s}

In 1991, Ethiopia entered another sphere of political reforms in a social and economic development system. The Ethiopian People's Revolutionary Democratic Front (EPRDF), an ethnic federalist political coalition, came to power after a decade and a half civil war, a war between the socialist government and oppositions. Clapham (2018) characterizes the EPRDF government as the clearest example of a 'developmental state' in Africa, which effectively captured "rents" from state monopoly of companies and forced loans accumulated from the private sector's deposits in government bonds to fund massive development projects. During the transitional period (1991-1995), the EPRDF government announced an agricultural development-led industrialization strategy as its overarching strategic framework for guiding Ethiopia's economic development and poverty reduction in 1993. They developed and promoted this strategy based on the 1960s and 70s development theories that commercialization of smallholder agriculture can ensure the availability of raw material for industrialization and drives economic growth (Ellis and Biggs, 2001; Alemu et al., 2002). The strategy aimed to intensify the use of GR technologies to boost smallholder farmers' agricultural production and productivity, increase food security, and achieve sustainable exports and import substitution. To implement it, the EPRDF government needed institutional reform for agricultural research, extension, and effective delivery of GR technologies, for which it requested financial assistance from donors (Spielman et al., 2010). At the time, the World Bank and International Monetary Fund (IMF) structural adjustment program had already begun to weaken public seed research and extension in developing countries (Bernstein, 1990; Bishaw and Louwaars, 2012).

Moreover, debates over the meaning and consequences of GR gave rise to a global environmental agenda affecting the development aid priorities of international donors (Sumberg et al., 2012). Amid these changes in international development politics, the EPRDF resisted the structural adjustment program and received substantial international assistance for agricultural research and development in Ethiopia. EPRDF got this privilege mainly because it dissociated Ethiopia from the alliance with socialist countries and new connections with western countries, and its commitment to democratic values and western economic policies (Clapham, 2019).

In 1992, the transitional government received USD 657.4 million from the World Bank, bilateral and multilateral donors to implement an emergency recovery and reconstruction program. The government allocated about 45\% (USD 296 million) of this funding to agricultural intensification (World Bank, 1998), of which USD 22 million went to seed system development projects between 1992 and 2002 (World Bank, 2003). The government used USD 50 million for agricultural extension services per annum, emphasizing the promotion of high-yielding 
varieties, chemical fertilizer, and pesticides among smallholder farmers (Spielman et al., 2012). In addition to the World Bank, the Sasakawa Africa Association and Global 2000 of the Carter Center (SG-2000) ${ }^{5}$ also made considerable investments in agricultural extension services, focusing on adopting the GR technologies since 1993 (Berhane et al., 2020). These investments helped revive the crop improvement research and development activities after a long period of low activity during the socialist regime. Although there has not been a time since the 1950s when public research and development was not a priority in government-led agricultural modernization, the investment in the second seed regime was very significant during the EPRDF government. At the time, the EPRDF transitional government issued a new constitution (FDRE, 1995) based on liberal and democratic principles to challenge the dominance of one political force in Ethiopia, effectively and ostensibly decentralizing power to regional and local authorities (Vaughan and Tronvoll, 2003). With the decentralization signal, the new constitution granted agricultural and rural development programs implementation responsibilities to newly formed autonomous regional states. Nine (currently eleven) regional states are "delimited based on the settlement patterns, language, identity, and consent of the peoples concerned" (FDRE, 1995, Article 46.2) under the federal government policy framework in Ethiopia. The corresponding sub-regional administrations, zones, and districts are responsible for agriculture and rural development at the local level (GebreEgziabher, 2014). With donor support, the EPRDF government implemented its decentralization policy of agriculture and rural development, including physical and institutional infrastructure development in the regions (Bechere, 2007). In the seed sector, it established Regional Agricultural Research Institutes, Regional Extension of the Bureaus of Agriculture, Regional Input Regulatory Authorities, and Regional Seed Enterprises in addition to preexisting national institutions in the formal seed system such as the EIAR, ESE, and EBI. Explaining the then needed decentralization of agricultural research and extensionwhich the government implemented in earnest during the 1990s with the financial support from donors-a high government official said:

\footnotetext{
"We [technocrats/experts/organizational leaders] were happy with the SG-2000 extension program and World Bank support. However, at the time, we noted a sharp increase in demand for improved seeds. Yet, we only had one public seed enterprise [the ESE] to produce and distribute certified seeds. Therefore, it was impossible to meet even half of the seed demand, especially for hybrid maize. So, the government decided to decentralize seed production and distribution by creating regional research institutes, parastatals ${ }^{6} . "$
}

\footnotetext{
${ }^{5}$ SG-2000 was established in Geneva in 1987 with the initiatives of Philanthropist Ryoichi Sasakawa (founder and former Chairman of The Nippon Foundation) who contacted Dr Norman Borlaug (the only Nobel Peace prize winner in food and agriculture until 2020), and President Jimmy Carter (who was involved in peace negotiation in Ethiopia in the late 1980s) following the 1970s and 1980s conflict and famine in the horn of Africa to solve food security problems.

${ }^{6}$ Personal interview with a government official of the Ethiopian Seed Enterprise (Addis Ababa, February 5, 2018).
}

In the 1990s, donor support was the key driver for the development of formal seed systems. In addition to the decentralization and capacity-building of public institutions for research and extension, the government developed and implemented a national seed policy framework throughout the 1990s (Figure 1B). The outcome was seed production and distribution increase, although it was impossible to fully meet the growing demand due to increased government extension programs' coverage after the decentralization (Gebreselassie, 2006). Arising from GR's realization, which began in earnest in the mid-1990s (Rohne Till, 2020) and continued agricultural growth (Berhanu and Poulton, 2014; Bachewe et al., 2015), the government embarked on a further formalization of the seed system, including the implementation of seed regulations. For instance, the government prioritized strengthening the formal supply of quality seeds of high-yielding plant varieties in almost all government policy documents ${ }^{7}$ on poverty reduction, food security, and agricultural growth and transformation until recently (Simane, 2008; Bishaw and Atilaw, 2016). One informant explained the 1990s government's seed system formalization and its constraints as follows:

\begin{abstract}
"The 1990s green revolution was the main triggering effect toward genuine seed system formalization in Ethiopia. As a result, the use of improved varieties and certified seeds would have increased significantly. But the lack of investment incentives for private seed companies and government-pricing of seeds affected the supply of quality seeds based on real competition ${ }^{8}$."
\end{abstract}

The statements from the above informants corroborate my analysis showing EPRDF resistance to seed sector liberalization and privatization and emphasis on government-led formal seed system development conforming to the developmental state model. The statements are also consistent with an explanation by one informant who described the failure of the World Bank support seed system project, especially the community-based seed production and distribution, which is one of the growing seed systems during the last decade, as discussed below. My informant said:

\begin{abstract}
"EPRDF refused to privatize the ESE and preferred to use the community-based seed production scheme supported by the World Bank as out-growers for the ESE instead of helping them to become viable seed entrepreneurs. The current expanding seed producer cooperative approach in the intermediate seed system is not new. It is the same World Bank type of project, but the
\end{abstract}

\footnotetext{
${ }^{7}$ The 1990s Agricultural Development Led Industrialization framework, National Five-Year Development Plan (2000-2004), Sustainable Development and Poverty Reduction Program (2002-2005), Plan for Accelerated and Sustained Development to End Poverty (2005-2010), The First Growth and Transformation Plan/GTP-I (2010-2015) and Second Growth and Transformation Plan/GTP-II (2015-2020).

${ }^{8}$ Personal interview with a senior researcher of the CGIAR (Addis Ababa, February 1, 2018).
} 
current one integrates business model and technical skill training of farmers in seed production and marketing ${ }^{9}$."

In agreement with Chinigò (2014), who examined the case of land administration in Ethiopia, my analysis shows that the decentralization of agricultural research and development is mainly an institutional expansion for strengthening the already hierarchical system of local administration and thereby extending the federal government's power to regions. In the seed sector, stringent federal regulations and centralized planning and control continued even after the decentralization of plant breeding, seed production, certification, and marketing in favor of the public seed sector. The EPRDF government resisted privatizing nearly all economic sectors, including land (Crewett et al., 2008), finance, and agriculture, for example, parastatal seed companies (Ojo and Ramtoolah, 2000; World Bank, 2003). Despite ideological differences between EPRDF and its donors $^{10}$ about the role of the private sector in economic development, Ethiopia has been a significant recipient (about USD 26 billion during the first two decades) of international development aid (Feyissa, 2011). Examined through Leach et al.'s (2020) food institution approach, we see the developmental state model overriding donors' neoliberal conditionalities to implement a competitive free market economy. According to Feyissa (2011) and Clapham (2018), EPRDF shielded Ethiopia from "neoliberal pressure" by playing a "sovereignty card" and placing itself diplomatically as a force for regional stability in an "unstable" region and as a leading partner in the Global War on Terror, for example as the largest contributor of troops (over 8,000) to UN peacekeeping. With the sovereignty narrative, which embodies power (Leach et al., 2020), and skillful negotiating strategy, Feyissa (2011) and Clapham (2018) argue that EPRDF buffered neoliberal influences. Seen through the food institution lens, donors' willingness to continue supporting Ethiopia is all about Cold War geopolitics and state alliances. Similarly, the EPRDF government's need for financial assistance did not mean that its political and economic development interests were the same as Western countries. As Feyissa's (2011) study shows, national sovereignty on policymaking and implementation was a priority for EPRDF.

Because the new constitution and EPRDF's agriculture and rural development policy also allowed non-state actors-including community-based organizations, local and international NGOs - to engage in development work and service delivery at the local level (Cerritelli et al., 2008), the PGRFA-movement coalitions (the EBI, local NGOs, and their partner western NGOs) continued to promote farmer-based seed system development. They promoted farmers' seed systems as an alternative to the dominant government-led formal seed

\footnotetext{
${ }^{9}$ Personal interview with a senior technical staffer of an NGO, Bilateral EthiopianNetherlands Effort for Food, Income and Trade Partnership (Addis Ababa, February 14, 2018).

${ }^{10}$ USAID, the World Bank, IMF, the European Union, Britain's Department for International Development (DFID), German Technical Cooperation (GTZ), Canadian International Development Agency (CIDA) and many other bilateral donors.
}

system and resistance to privatization. At the international level, the rise of the environmental agenda favored the proponents of the global PGRFA movement to intensify the seed contestation and movements through project implementation and policy advocacy (Cromwell et al., 1993, pp. 71-75). This movement contributed to Ethiopia adopting international agreements such as the United Nations Convention on Biological Diversity and the International Treaty on Plant Genetic Resources for Food and Agriculture (ITPGRFA) and corresponding funding mechanisms for supporting projects for their implementation. In Ethiopia, donor-funded projects strengthened the on-farm PGRFA management (e.g., participatory variety selection, community seed banking) during the 1990s (Mulesa and Westengen, 2020). There are two main reasons for reinforced support to implement community-based PGRFA management and farmers' seed systems. First, the Ethiopian delegates played a prominent role in international negotiations related to biodiversity agreements (Gebre Egziabher et al., 2011), which earned the country an international reputation as a progressive country in environmental governance. Second, Ethiopia's community-based PGRFA management work since the late 1980s (Worede, 1997) attracted international development actors for exchange and experience sharing with other developing countries (Dalle and Walsh, 2015). That said, the state's financial and institutional support primarily went to conventional GR seed research and development. The financial support provided for community-based PGRFA management projects was much less (about USD 5 million) than the funding that formal seed system development received (over USD 22 million) over 10 years period (Worede, 1991; IBC, 2007). Although implementation was incomplete, the government issued several policies and legislation to favor the farmers' seed systems. Recent studies provide an overview of these policy frameworks, which the EPRDF government issued in favor of farmers' seed systems in Ethiopia, and of the status of their implementations (Beko, 2017; Mulesa and Westengen, 2020; Mulesa et al., 2021).

Despite seed contestation and movements promoting farmers' seed systems since the mid-1980s, its role in supplying the most considerable quantities of crop varieties and seeds, and the approval of supportive policy frameworks, the EPRDF government continued prioritizing government-led formal seed system development. Viewed from a food innovation systems perspective (Thompson and Scoones, 2009; IPES-Food, 2016), we see agricultural modernization and the continuation of the historical legacies of the Ethiopian government's political interests and incumbent powers for top-down control of farmers by ignoring alternative development pathways to the formal seed system. Studies link the regime's predominant focus on supplying agricultural input through public institutions, including certified seeds, as an instrument for securing political control of rural constituencies throughout Ethiopia. These studies also show how wealthier model farmers benefit from government input supply at the expense of poor farmers (Lefort, 2012; Berhanu and Poulton, 2014; Hailemichael and Haug, 2020). The modernization path dependencies or "lockins" to agricultural development and government-led formal seed 
TABLE 1 | Dominant and alternative pathways to policy practices in Ethiopia's pluralistic seed system development.

\section{Dimensions of policy Government-led seed system}

practice

formalization
Dominant approach

and underlying

narratives for seed

policy-making and

actors' actions

\section{Agricultural growth and}

Government institutions and

public seed research and development

(GR) technologies ${ }^{a}$ to increase agricultural

production and productivity. On this account,

national food and nutrition security can

improve, and agriculture-led industrialization

can accelerate.

Actors' coalitions

articulating the

dominant narratives

Main critiques and

actors' coalitions

enunciating it

Ministry of Agriculture; the Ethiopian

Agricultural Transformation Agency; extension

and input supply authorities; input regulatory and unions; the ruling party

Proponents of private-led formalization:

Centrally planned ineffective seed production

and marketing cause untimely supply and
Federal, regional, and international agricultural Private seed companies (national and research institutions; public seed enterprises; multinational); Ethiopian Seed Association;

poor-quality certified seeds. Consequently,

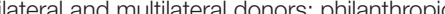

Africa; the Ethiopian Agricultural Transformation program

Agency; International agricultural research

institutions

Proponents of localization: Access to certified eeds is difficult for poor farmers due to high seed prices. Privatization creates a dependency on few improved varieties, drives seed carryover arises, and farmers demand is genetic erosion, and creates seed enclosure unmated; the private sector should replace the and food control by a few powerful seed public seed research and development institutions. companies. Proponents of localization: The top-down seed Relying on the private sector is inadequate. research and development distribute poor-quality seeds that are less adapted to farmers' diverse agro-ecological and They cannot meet national seed security needs due to their focus on commercially success crops and profit; therefore, government socio-economic needs and poses production intervention is necessary risky, especially for poor farmers and farmers in marginal areas.

Proponents of integration: Centralized, Proponents of integration: Seeds from private companies are expensive for some commercial $P$ farmers, and seed producer cooperatives can Production, offer affordable quality seeds. and distribution of certified seed makes timely access to seeds difficult, which requires complementary local seed businesses. authorities; multipurpose farmers cooperatives

\section{Farmer-based seed system localization}

Biodiversity-based sustainable

agriculture-Government policies and

investments that prioritize market-led GR

technology supply have been ineffective to meet the diverse agro-ecological,

socio-cultural, and economic needs, and

people's livelihoods. The approach has

jeopardized smallholder farming. Therefore, strengthening farmers' knowledge, practices, and institutions for supplying locally adapted crop varieties can have the potential to satisfy these diverse needs and sustain stable crop production.

Ethiopian Biodiversity Institute, Local and western NGOs; Bioversity International; FAO's iSSD have limited knowledge and skill in quality seed Commercial seed production and marketing by production, and they supply low-quality seeds farmers bring unnecessary competition in the of variable quantities. national seed industry, especially for

Proponents of formalization (public): Promotion economically critical commercial crops.

of local varieties should not be at the expense Farmers have limited technological know-how of the government agricultural transformation in commercial seed production and marketing plan (i.e., use of a complete package of improved varieties, chemical fertilizer, in commercial seed production and marketing, and their seed business must be limited to local crops to avoid productivity loss.

pesticides, and improved agronomic practices)

The nation crop production and productivity.

guaranteeing the conservation of crop diversity.

(ill training and

Provision of agricultural infrastructure (e.g.

seed cleaning and storage facilities) for

collective seed production and marketing can

improve farmer-based seed production,

storage, and marketing. Therefore, market

orientation is necessary for sustainable local

seed supply. 


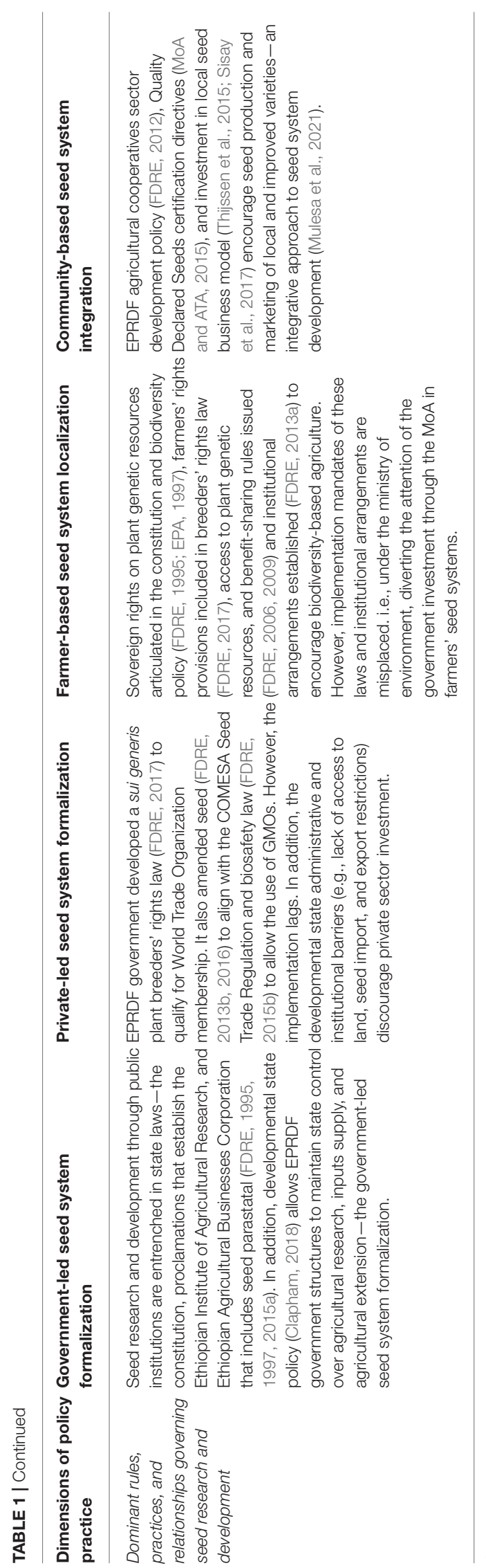

system development have continued even after the launch of the PSSDS, as I discuss below.

\section{AGAINST THE GRAIN: THE EMERGENCE OF PSSDS AND ITS IMPLEMENTATION PATHWAYS}

Since the mid-1980s, diverse coalitions of actors have promoted alternative pathways to seed system development following the food and agricultural crisis. These alternatives (Table 1) were debated intensely for about 8 years, beginning in 2006 until the Ethiopian Agricultural Transformation Agency (ATA) ${ }^{11}$ and MoA released the first version of the PSSDS in 2013 (MoA and ATA, 2017). The PSSDS in Ethiopia was the result of an externally funded intensive 1-year tailor-made training program ${ }^{12}$ based on a multi-stakeholder process approach (Thijssen et al., 2008; ICARDA, 2009) and the Integrated Seed Sector Development (ISSD) program ${ }^{13}$ that emerged from this process (CDI, 2009) and played a catalytic role by bringing diverse seed sector actors together. These actors debated policy and governance issues related to the different seed system development alternatives at different levels during the training. The debate continued during the first phase of the ISSD program implementation (2009-2011) and the PSSDS process under the auspices of the Ethiopian ATA (2011-2013). Overall, the impact of the externally funded 1year training program and the ISSD program was significant in facilitating the PSSDS development (ICARDA, 2009; Borman et al., 2020). There are three major discourses in the contestation surrounding the current Ethiopian seed regime (privatization, localization, and integration) proposed by different actors while

\footnotetext{
${ }^{11}$ The establishment of Ethiopian ATA was initiated by the late Prime Minister Meles Zenawi after he approached Melinda Gates, Co-Chair of the Bill and Melinda Gates Foundation (BMG Foundation), and asked for the Foundation's support in identifying an innovative way to catalyze agricultural growth and transformation in his country. Following this request, the BMG Foundation financed a study that identified the lack of intersectoral coordination and integration within the agriculture sector, and implementation capacity as the main hindrances. Addressing this would require an organ to streamline coordination and transformation activities. In 2010, the Council of Ministers established ATA (Regulation No. 198/2010) as an autonomous federal organ to: (i) provide leadership in identifying, designing and effectively implementing solutions to basic hurdles in agricultural development; and (ii) provide policy directions and leadership in order to ensure that effective coordination is realized by different actors involved in agricultural development (FDRE, 2010).

${ }^{12}$ The training program was supported by the Dutch Government through Wageningen Centre for Development Innovation of the Wageningen University and Research under a project titled "the improvement of farmer-based seed production scheme and revitalizing farmers' seed supply of local crops and varieties in Ethiopia." The project was implemented in partnership with International Center for Agricultural Research in the Dry Area's Seed Unit and the Ethiopian Seed Enterprise in 2006 (Thijssen et al., 2008; ICARDA, 2009).

${ }^{13}$ The ISSD program is part of the "Bilateral Ethiopia-Netherlands Effort for Food, Income and Trade Partnership supported by the Dutch Government through the Embassy of the Kingdom of the Netherlands in Addis Ababa since 2009. The Centre for Development Innovation of Wageningen University and Research Centre and the Royal Tropical Institute, the Netherlands, is operationalizing the ISSD program. It implements the program to support the African Seed and Biotechnology Program of the African Union Commission (African Union, 2008) through its local partners in Ethiopia, Mozambique, Nigeria, and Uganda.
} 
formulating the PSSDS in addition to the government-led formal seed system (Table $\mathbf{1}$ ).

Proponents of private-led seed system formalization have been working to increase the roles of private actors in plant breeding and commercial seed production and marketing in Ethiopia, which has not yet been anchored in the country's formal seed system. For instance, they supported policy and regulatory reform, e.g., the development of plant breeders' rights and seed laws, seed quality control by seed companies, and capacitybuilding of government agencies for effective seed certification. They also provide financial and technical support for start-ups and small seed companies (O'Connor Funk, 2009; Holtzman et al., 2020). The donor and philanthropic support that goes to private-led seed system formalization is mainly a renewed commitment from the international community to invest in African agriculture following the food crisis that struck the world in 2008 (Scoones and Thompson, 2011). But it can also be piggybacking on the influence of other actors' protests against the dominance of government-led seed research and development, as discussed below.

Most of the coalition of the second group of actors subscribing to the localization discourse has supported the seed contestation and movements (the PGRFA movement) at different times to strengthen farmer-based seed system localization since the mid1980s (Cromwell et al., 1993). As a protest against privatization or seed enclosure through IPRs, and ineffective governmentled seed supply systems, they have promoted participatory plant breeding, community seed banks, farmers' rights, and less stringent seed certification processes for seed producer groups' local seed marketing (Feyissa et al., 2013; Gotor et al., 2014). The third pragmatic coalition group of actors is proponents of the seed system modernization. They endorse the integration of formal and farmers' seed systems that are neither governmentled nor private-led formalization but are instead a pragmatic approach to seed sector development. Building on experiences of the World Bank seed system project that partly supported community-based seed production and distribution in the 1990s, the coalition of these actors has supported the integration of formal and informal seed systems through SPCs. At the SPCs level, they support infrastructure development, skill training in planning, production, processing, packaging quality seeds, organizational governance, marketing strategy, and business management. For this purpose, they support the supply of early generation seeds of improved varieties to SPCs from agricultural research and quality declared seed certification schemes for seed marketing (Sisay et al., 2017; Borman et al., 2020). For example, the participation of some actors such as the ISSD program, ATA, and research institutions in the formal and local seed system while promoting the integrative community-based approach demonstrates their pragmatic approach to seed innovation.

These three alternatives in the PSSDS are competing with one another and the dominant government-led formal seed supply system. The seed sector privatization alternative seeks market-based seed supply of profitable crops, which increases commodification and seed enclosure through IPRs protection. It aims to access basic agricultural inputs (e.g., land) to have its breeding program, developed its crop varieties, and access improved varieties bred through public research for seed multiplication and marketing. Moreover, it aims to exclude other actors (e.g., public seed enterprises and SPCs) from certified seed production and marketing of target crops (e.g., hybrid maize). The localization alternative resists IPRs and privatization in favor of farmers' rights and aims to build local capacity to produce and distribute locally adapted seeds using non-market channels. Proponents of localization blame the government-led formal system for seed insecurity owing to ineffectiveness, despite the investment priorities it received from the government over the past decades. In return, the actors supporting government-led formal seed supply believe that an investment that promotes local varieties could impair the government's agricultural transformation. The integrative alternative seeks to increase local availability and access to quality declared seeds of diverse improved and local varieties with farmer-preferred traits. The alternative prioritizes the marketing of open-pollinated crops that the government-led formal seed supply has ignored for decades. Table 1 shows how different actors' coalitions framed seed system development through particular discourses to promote specific policies and interventions to remedy their problem definitions. It also shows that the government-led formal seed system remains the dominant alternative despite critiques from opponents.

The actors' coalition narratives, values and goals, and priorities based on knowledge politics and dynamics of power led to adopting a pluralistic seed system. However, the direction, diversity, distributional effects, and democratic participation in PSSDS implementation show challenges, as I discuss below.

Moreover, there is growing optimism about possible liberalization and privatization of Ethiopia's agri-food system, including the seed sector, following a leadership change and reforming the developmental state's political and economic policies since 2018 (Geleti, 2020; Woolfrey et al., 2021). A widespread youth protest was an everyday experience between 2015 and 2018 due to two-and-a-half decades of growing inequality and multiple forms of youth exclusions from the developmental state's development future that unequally distributed the fruits of economic growth. Contestations around violent forms of government land-grabbing, farmer dispossession, youth unemployment, lack of political freedom, and human rights violations were at the core of the youth protest. This protest brought the "reformist" Prime Minister Abiy Ahmed to power in April 2018 (Abebe, 2020). The seed sector privatization optimism links to Prime Minister Abiy Ahmed's recent Homegrown Economic Reform Program of making Ethiopia the African icon of prosperity by 2030. The program received USD 5 billion from the IMF and the World Bank in 2019 and USD 3 billion from the United Arab Emirates in 2018, owing to its prioritization of the private sector (Collier, 2019; Kibsgaard, 2020). With this recent economic reform, the MoA has already issued a new strategy in 2019 to strengthen the private seed sector (MoA, 2019). However, when writing this paper, Ethiopia faces a political rift that has led to civil war, making the future uncertain (Walsh and Dahir, 2021; Ylönen, 2021). As a result, some western donor countries are undertaking evidence-based analysis of the country's fragility to 
make informed bilateral relations and investment policies for the future (Rameshshanker et al., 2020).

\section{THE "4Ds" OF ETHIOPIA'S CURRENT SEED POLICY AND PRACTICE}

Following Leach et al.'s (2020) 4D approach to the study of food politics and development, I assess the outcomes of the PSSDS through four questions: What has been the direction of the seed system development; What diversity of technical and institutional innovations have resulted, to what extent has the development been democratic and inclusive and; what have been the distributional outcomes for marginalized people.

The direction of seed system development under Ethiopia's PSSDS framework is still the dominant government-led formal seed system emphasizing the development and use of GR technologies, including improved varieties as a response to food and nutrition insecurity, climate change, and rural poverty. This dominance is also unexpected given that Ethiopia is the most significant international aid recipient and has approved policies and strategies on paper in favor of a free-market economy, including privatization. It shows the marginal effect of donor influence compared to other developing countries where power asymmetry between governments and donors is at play in setting seed sector development policies (Scoones and Thompson, 2011). One respondent explained how the dominance of the public seed sector (e.g., in major food crops) had been maintained by the Ethiopian government as follows:

\begin{abstract}
"Our developmental state fears that there could be a risk of food insecurity if competent private seed companies overtake the public enterprises and cannot supply affordable seeds, especially for food crops like hybrid maize. They do not say it, but we know they also fear a loss of political support and income if the private sector overtakes the public enterprise and extension services for the key food security crops. However, the government is for competent private seed companies in horticulture to increase foreign currency gain from seed and food exports. Still, institutional capabilities are too poor to appropriately implement existing policies and laws, such as the revised plant breeders' rights protection law in 2017, which discourages companies from entering the sector ${ }^{14}$."
\end{abstract}

The state's power as entrenched in developmental state policy and skillful negotiation with donors that continue to support the GR approach to agricultural development is the driving force for this dominant path. Describing state power and development practices in government institutions, one informant with intimate knowledge of Ethiopian seed policy said:

"Ethiopia's developmental state economic policy goes beyond directing, supporting, and guiding executive bodies of public institutions because the government wants to implement everything related to agricultural development by itself. The organizational leaders that I have interacted with told me that

\footnotetext{
${ }^{14}$ Personal interview with a senior technical staffer working for donor funded seed system development program (Addis Ababa, January 18, 2018).
}

they must deliver inputs, including certified seeds, to farmers. The agriculture bureaus at the regional, zonal, and district levels think that seed distribution is their primary responsibility, and others cannot play a central role except helping them. They believed that public parastatals should be the leading seed producer, and the extension at the bureau of agriculture is responsible for its distribution to farmers through cooperatives. I see a symbiotic relationship between government staff unwilling to give up the seed distribution job to agro-dealers and government use of seed as a political commodity, i.e., maintaining strong links with and controlling farmers ${ }^{15}$."

Explaining the continued donor supports, despite the government's unwillingness to sign up to neoliberal institutions and encourage seed sector liberalization and privatization, one informant said:

\begin{abstract}
"Several donors such as BMG Foundation, USAID, the World Bank, and the Dutch government have provided aid for agricultural research and development during the past decade in Ethiopia. Simultaneously, they have been pushing for policies for seed sector privatization. For example, they provided technical and financial assistance through AGRA, ATA, ESA, and the ISSD program to develop seed and PVP laws ${ }^{16}$. The government approved these laws, but they are not enforcing them, making it difficult for the private sector to operate. For example, the DUS test and issuing of PVP certificate is almost nil as there are no directives issued, making variety import and export very difficult for the private companies. On top of this, regulatory services at the federal level are centralized and bureaucratic. Besides, Ethiopia has not acceded to the WTO and is unwilling to join UPOV. Unfortunately, the government continues to discourage privatization, and it is not easy to change the government's [politicians/executive leaders] negative attitude toward the private sector ${ }^{17}$."
\end{abstract}

In addition to community seed banks that EBI and NGOs promoted since the 1990s in Ethiopia, community-based seed production and marketing (through SPCs) emerged as an additional alternative during PSSDS formation and its implementation. As a result, the SPCs and community seed banks have contributed to the diversification of the country's seed systems regarding farmers' choice of crops, varieties, and seed sources (Sisay et al., 2017; Alemu et al., 2019; Andersen, 2019).

The distributional effect of dominant government-led seed research and development that marginalized the private sector in the formal system and farmers' seed systems is evident from a recent field study conducted on farmers' seed security in the central highlands in Ethiopia (Mulesa et al., 2021). The study identified seed insecurity in a commercially oriented wheat farming district and a subsistence-oriented tef (Eragrostis tef) growing community. The study links the limited availability

\footnotetext{
${ }^{15}$ Personal interview with a senior technical staffer working for donor funded seed system development program (Addis Ababa, January 18, 2018).

${ }^{16}$ Acronyms: Alliance for a Green Revolution in Africa (AGRA), Ethiopian Agricultural Transformation Agency (ATA), Ethiopian Seed Association (ESA), Integrated Seed Sector Development (ISSD) and Plant Variety Protection (PVP).

${ }^{17}$ Personal interview with a senior manager working for donor funded seed system development program (Addis Ababa, February 1, 2018).
} 
of improved varieties and specially certified seeds of these to the ineffectiveness of the public institutions and the availability of few commercial actors. The PSSDS acknowledges the importance of diversity on paper, but the bias of supporting the dominant modernization approach is pulling in another direction. However, it is important to note that Ethiopia's seed system is mainly farmer-based, and agriculture is-in comparison to most of the world-highly diverse in terms of crops, varieties, and seed sources. We also observe a lack of locally adapted varieties linked to a lack of democratic participation in priority setting, technical and institutional innovation, for example, with priority crops for breeding, participatory variety development of such crops, and involvement in policy processes (Beko, 2017). For instance, farmers in wheat and maize growing agro-ecologies benefited from the formal seed system more than those growing other indigenous crops due to the concentration of the public breeding, dissemination, and adaptation work in the two crops since the first GR. Moreover, farmers' differentiated access to preferred seed and information (including wheat and maize commercial areas) according to sex, age, and wealth, links to gender inequality and political allegiance that the developmental state extension institutions use to select model farmers, favoring the wealthier ones for seed access.

\section{CONCLUSIONS}

This article analyzed the historical evolution and current policy practices in the Ethiopian seed sector development, focusing on actors' interests and actions and political and economic priorities of three different governance regimes (imperial, socialist, and developmental) since the 1950s. Despite agricultural policy changes from commercial farming of the feudal system to state enterprises and cooperativization of the socialist government to the developmental state's commercialization of smallholder farmers, all governance regimes have retained public seed research and development in Ethiopia. Moreover, these governance regimes also held public seed research and development as a priority despite awareness, recognition, and policies on paper about how diverse seed systems can increase access to enough good quality seeds of suitable plant varieties by farmers.

The power analysis allowed me to identify some insights concerning this specific Ethiopian seed policy and practice. Of historical significance is Ethiopia's idiosyncratic historical patterning of the seed regimes compared to most colonial territories and industrial countries. The first colonial seed regime never took hold, and the third corporate seed regime has never been anchored in the formal seed system. Consequently, Ethiopia's seed system development remains government-led. Related to this, we see two paradoxical aspects of Ethiopian government policy practices. First, the Ethiopian governments have received financial assistance from western donors, including neoliberal financial institutions, while disagreeing with them and establishing the distinct seed sector development policies in line with the agricultural development ideology of the governance regimes. For example, the EPRDF government has received funding from the IMF and the World Bank to finance public agricultural research and development, including during the structural adjustment program in the 1990s. Still, Ethiopia is not a member of WTO and UPOV ${ }^{18}$, which are the key neoliberal seed institutions. Second, Ethiopia's positions in environmental governance, climate change, and UN development goals are perceived as "progressive" on the international scene. At home, the government has sidelined alternative development pathways in support of these positions. For example, support for the farmers' seed systems mainly comes from multilateral institutions, local and international NGOs.

Ethiopia has a very centralized and top-down state-led seed sector development policy. Practically, the government has sidelined both its development partners' democratic values and neoliberal economic policies as well as measures to implement its policies on alternatives to the dominant public seed research and development. That said, the two perspectives have common ground in notions of independence, sovereignty, skepticism against foreign forces, liberalization, and free-market ideology. In the end, the government investment emphasizes state-led seed sector development, leaving other alternatives to NGOs and smaller overseas development assistance projects. While heavily dependent on external funding, the Ethiopian example of paradoxical state-led policy development and action exemplifies variations specific to countries in international politics and development work.

In line with other studies (Alemu, 2011; Beko, 2017), we see a link between the nature of the Ethiopian state and the marginalization of alternative seed sector development in the country. Decades of centralized planning and execution of agricultural development, state control of rural constituencies, elite interests, and agricultural modernization path dependency have contributed to the lack of inclusive and equitable seed sector development. In addition, the historical events and processes are vital elements that have shaped the practices of the Ethiopian state in the governance of seed sector development. For instance, the limited participation of the private sector in the formal seed system links to the first colonial seed regime that never took hold in Ethiopia compared to other African countries such as neighboring Kenya, which has signed over to the neoliberal institutions. In agreement with McCann (2011), we see that policymaking and implementation in Ethiopia treat external influences and the international seed market as of lesser importance. Again, resonating with McCann's (1990) observation, we find that the state and elite's vested interest in maintaining the status quo of the agricultural cycle for resource extraction from the farming community is the major hindrance to breaking the cycle and bringing an inclusive and equitable seed sector development to Ethiopia.

For inclusive and equitable seed sector development to happen in Ethiopia, there needs to be a political will to establish effective institutional arrangements and allocate an adequate budget for the recent PSSDS. One motivating factor or source of inspiration in this direction is the growth of

\footnotetext{
${ }^{18}$ WTO is the acronym for World Trade Organization and UPOV is the acronym for Union Internationale pour la Protection des Obtentions Végétales (French) or International Union for the Protection of New Varieties of Plants (English), which is also the name of the organization that established the International Convention (called the UPOV Convention).
} 
community-based seed production and marketing. However, other matters deserving attention are the biased attitudes and bad governance, including legal hurdles in the seed sector that marginalize other alternatives and actors, for instance, farmerbased seed system innovation and participation of the private sector in seed research and development.

Finally, when applying Leach et al.'s (2020) plural approaches to power analysis in developing countries, it is vital to carry out a historical analysis of the policies and institutions involved in seed system governance, as this study has done in the case of Ethiopia. Analyzing seed regime patterns allows one to examine how historical conflicts or cooperation between donors and governance regimes have shaped distinct seed policies and practices in developing countries. In considering the particular historical, political, and institutional factors within each country, a more nuanced picture is created by going beyond existing institutional, infrastructure, and financial limitations that donors often focus on for their intervention.

\section{DATA AVAILABILITY STATEMENT}

The raw data supporting the conclusions of this article will be made available upon request to the author.

\section{ETHICS STATEMENT}

The study was conducted according to the guidelines for research ethics of the Norwegian University of Life Sciences and Norway's guidelines for research ethics in the social sciences, humanities, law, and theology. A notification form was submitted to the Norwegian Center for Research Data (NSD) before data collection based on these guidelines, and approval was received from NSD (Harald Hårfagres gate 29, N-5007 Bergen, Norway)

\section{REFERENCES}

Abebe, T. (2020). Lost futures? Educated youth precarity and protests in the Oromia region, Ethiopia. Children's Geogr. 18, 584-600. doi: $10.1080 / 14733285.2020 .1789560$

African Union (2008). African Seed and Biotechnology Programme. AfricaSeeds. Available online at: https://www.africa-seeds.org/wp-content/uploads/2016/ 11/ASBP-Document.pdf (accessed January 2, 2021).

Alemu, D. (2011). The political economy of Ethiopian cereal seed systems: state control, market liberalisation and decentralisation. IDS Bull. 42, 69-77. doi: 10.1111/j.1759-5436.2011.00237.x

Alemu, D., Koomen, I., Schaap, M., Ayana, A., Borman, G., Elias, E., et al. (2019). BENEFIT Partnership-2019 Annual Report: Bilateral Ethiopian-Netherlands Effort for Food, Income and Trade Partnership. Wageningen: Wageningen Centre for Development Innovation.

Alemu, Z. G., Oosthuizen, L. K., and Van Schalkwyk, H. (2002). Agricultural development policies of Ethiopia since 1957. South Afr. J. Econo. History 17, 1-24. doi: 10.1080/10113430209511142

Almekinders, C. J. M., and Louwaars, N. P. (2002). The importance of the farmers' seed systems in a functional national seed sector. J. New Seeds 4, 15-33. doi: 10.1300/J153v04n01_02

Amanor, K. S. (2011). From farmer participation to pro-poor seed markets: the political economy of commercial cereal seed networks in Ghana. IDS Bull. 42, 48-58. doi: 10.1111/j.1759-5436.2011.00235.x

Andersen, R. (2019). The Impact of the Development Funds' and EOSA's Community-Based Agrobiodiversity Management Programme in Ethiopia. Lysaker: Fridtjof Nansen Institute. on 18.09.2017. The guidelines did not require explicit ethics approval in Ethiopia. However, I informed the authorities, which gave a letter of permission to carry out the interviews and discussions. Voluntary informed consent was obtained from all research participants after explaining the research project's objectives, the implication of their participation, and how their information is used.

\section{AUTHOR CONTRIBUTIONS}

The author confirms being the sole contributor of this work and has approved it for publication.

\section{FUNDING}

This research was funded by the Research Council of Norway. Grant Numbers are RCN-277452 and RCN-288493.

\section{ACKNOWLEDGMENTS}

This article is based on a research project conducted in completion of the Ph.D. degree by the author. The author would like to thank all interviewees for their time and contributions to this study. The author also thanks Ola T. Westengen and Ruth Haug in Norwegian University of Life Sciences (NMBU) for their guidance and invaluable help throughout this research project. The author wishes to thank the NMBU for the scholarship to carry out this research and the Research Council of Norway (RCN) for financial support under grant numbers RCN-277452 and RCN-288493. The author is thankful to the International Maize and Wheat Improvement Center (CIMMYT) in Addis Ababa for hosting him and facilitated his fieldwork during the period.

Ariga, J., Mabaya, E., Waithaka, M., and Wanzala-Mlobela, M. (2019). Can improved agricultural technologies spur a green revolution in Africa? A multicountry analysis of seed and fertilizer delivery systems. Agri. Econo. 50, 63-74. doi: 10.1111/agec.12533

Austin, G. (2009). Cash crops and freedom: export agriculture and the decline of slavery in colonial West Africa. Int. Rev. Soc. Hist. 54, 1-37. doi: 10.1017/S0020859009000017

Bachewe, F. N., Berhane, G., Minten, B., and Taffesse, A. S. (2015). Agricultural Growth in Ethiopia (2004-2014): Evidence and Drivers. Washington, DC: International Food Policy Research Institute (IFPRI).

Bechere, E. (2007). Agricultural Research and Development in Ethiopia International Conference on Ethiopian Development Studies (4th ICEDS): A Multidisciplinary Conference on the Challenges of Peace and Development in Ethiopia \& the Horn of Africa, Kalamazoo, Michigan (WMU). Available online at: https://scholarworks.wmich.edu/africancenter_icad_archive/127 (accessed August 4, 2007).

Beko, M. H. (2017). Seed for change: the making and implementation of seed policies in Ethiopia ( $\mathrm{PhD}$ thesis). Wageningen University, Wageningen, Netherlands.

Belay, K. (2003). Agricultural extension in Ethiopia: the case of participatory demonstration and training extension system. J. Soc. Dev. Afr. 18, 49-84. doi: 10.4314/jsda.v18i1.23819

Belete, A., Dillon, J. L., and Anderson, F. M. (1991). Development of agriculture in Ethiopia since the 1975 land reform. Agri. Econ. 6, 159-175. doi: 10.1111/j.1574-0862.1991.tb0 0177.x

Berhane, G., Ragasa, C., Abate, G. T., and Assefa, T. W. (2020). "Ethiopia," in Agricultural Extension: Global Status and Performance in Selected Countries, eds 
K. E. Davis, S. C. Babu, and C. Ragasa (Washington, DC: International Food Policy Research Institute), 185-224.

Berhanu, K., and Poulton, C. (2014). The political economy of agricultural extension policy in Ethiopia: economic growth and political control. Dev. Policy Rev. 32, S1467-S7679. doi: 10.1111/dpr.12082

Bernstein, H. (1990). Agricultural 'modernisation' and the era of structural adjustment: observations on sub-Saharan Africa. J. Peasant Stud. 18, 3-35. doi: 10.1080/03066159008438441

Bezner Kerr, R. (2013). Seed struggles and food sovereignty in northern Malawi. J. Peasant Stud. 40, 867-897. doi: 10.1080/03066150.2013.848428

Bishaw, Z., and Atilaw, A. (2016). Enhancing agricultural sector development in ethiopia: the role of research and seed sector. Ethiopian J. Agri. Sci. 1, 101-129. Available online at: https://hdl.handle.net/20.500.11766/7637

Bishaw, Z., and Louwaars, N. (2012). "Evolution of seed policy and strategies and implications for Ethiopian seed systems development," in Defining Moments in Ethiopian Seed System, eds T. W. Adfris, F. Asnake, A. Dawit, D. Lemma, and K. Abebe (Addis Ababa: Ethiopian Institute of Agricultural Research).

Bondestam, L. (1974). People and capitalism in the north-eastern lowlands of Ethiopia. J. Modern Afr. Stud. 12, 423-439. doi: 10.1017/S0022278X0000971X

Bonneuil, C. (2000). Development as experiment: science and state building in late colonial and postcolonial Africa, 1930-1970. Osiris 15, 258-281. doi: $10.1086 / 649330$

Borman, G., Hassena, M., Verhoosel, K., and Molenaar, J. W. (2020). Guiding Sector Transformation: The Case of Integrated Seed Sector Development in Ethiopia. Wageningen: Wageningen Centre for Development Innovation.

Borras, J. R., Saturnino, M., Edelman, M., and Kay, C. (2008). Transnational agrarian movements: origins and politics, campaigns and impact. J. Agrar. Change 8, 169-204. doi: 10.1002/9781444307191.ch1

Brietzke, P. (1976). Land reform in revolutionary Ethiopia. J. Modern Afr. Stud. 14, 637-660. doi: 10.1017/S0022278X0005374X

Brink, M. (2013). Historical Overview of On-Farm Conservation of Plant Genetic Resources in Ethiopia, and Lessons Learned. Wageningen: Centre for Genetic Resources (CGN); Wageningen University and Research Centre (WUR).

Brush, S. B. (1992). Reconsidering the green revolution: diversity and stability in cradle areas of crop domestication. Human Ecol. 20, 145-167. doi: $10.1007 / \mathrm{BF} 00889077$

Byerlee, D. (2020). The globalization of hybrid maize, 1921-70. J. Global History 15, 101-122. doi: 10.1017/S1740022819000354

CDI (2009). Integrated Seed Sector Development (ISSD) in Ethiopia. Wageningen: Centre for Development Innovation. Available online at: https://issdethiopia. org/ (accessed November 10, 2020).

Cerritelli, W. E., Bantirgu, A., and Abagodu, R. (2008). Updated Mapping Study of Non State Actors in Ethiopia. Addis Ababa: European Commission. Available online at: http://www.eeas.europa.eu/archives/delegations/ethiopia/ documents/eu_ethiopia/ressources/regional_reports_en.pdf

Chinigò, D. (2014). Decentralization and agrarian transformation in Ethiopia: extending the power of the federal state. Crit. Afr. Stud. 6, 40-56. doi: 10.1080/21681392.2014.853986

Clapham, C. (1988). Transformation and Continuity in Revolutionary Ethiopia. Vol. 61. Cambridge: Cambridge University Press.

Clapham, C. (2018). The Ethiopian developmental state. Third World Q. 39, 1151-1165. doi: 10.1080/01436597.2017.1328982

Clapham, C. (2019). "The political economy of Ethiopia from the Imperial period to the present," in The Oxford Handbook of the Ethiopian Economy, eds F. Cheru, C. Cramer, and A. Oqubay (Oxford: Oxford University Press), 33-47.

Clapp, J. (2012). Food. Cambridge: Polity Press.

Clapp, J. (2021). The problem with growing corporate concentration and power in the global food system. Nat. Food. 2, 404-408. doi: 10.1038/s43016-02100297-7

Clawson, D. L. (1985). Harvest security and intraspecific diversity in traditional tropical agriculture. Econ. Bot. 39, 56-67. doi: 10.1007/BF028 61175

Cohen, J. M. (1974a). Peasants and Feudalism in Africa: the case of Ethiopia. Can. J. Afr. Stud. 8, 155-157.

Cohen, J. M. (1974b). Rural change in Ethiopia: the Chilalo agricultural development unit. Econ. Dev. Cult. Change 22, 580-614.

Cohen, J. M. (1975). Effects of green revolution strategies on tenants and smallscale landowners in the Chilalo region of Ethiopia. J. Dev. Areas 9, 335-358.
Cohen, J. M., and Isaksson, N.-I. (1988). Food production strategy debates in revolutionary Ethiopia. World Dev. 16, 323-348. doi: 10.1016/0305-750X(88)90001-0

Collier, P. (2019). Ethiopia's path to prosperity is opening up under Abiy Ahmed. Financial Times. Available online at: https://www.ft.com/content/502dc8f4ef62-11e9-a55a-30afa498db1b

Coomes, O. T., McGuire, S. J., Garine, E., Caillon, S., McKey, D., Demeulenaere, E., et al. (2015). Farmer seed networks make a limited contribution to agriculture? Four common misconceptions. Food Policy 56, 41-50. doi: 10.1016/j.foodpol.2015.07.008

Cooper, D., Vellve, R., and Hobbelink, H. (eds.). (1992). Growing Diversity: Genetic Resources and Local Food Security. London: Intermediate Technology Publications.

Correa, C. M. (2015). Plant Variety Protection in Developing Countries: A Tool for Designing a Sui Generis Plant Variety Protection System: An Alternative to UPOV 1991. Berne: Association for Plant Breeding for the Benefit of Society (APBREBES). p. 94.

Crewett, W., Bogale, A., and Korf, B. (2008). Land Tenure in Ethiopia: Continuity and Change, Shifting Rulers, and the Quest for State Control. Washington, D.C.: International Food Policy Research Institute (IFPRI).

Cromwell, E. (1992). The Impact of Economic Reform on the Performance of the Seed Sector in Eastern and Southern Africa. Paris: OECD Development Center. Available online at: https://www.oecd-ilibrary.org/docserver/ 523245475740.pdf? expires $=1622475760 \& i d=i d \& a c c n a m e=$ guest $\&$ checksum $=$ 2EA5222A451815B06E2E46CF362F9017

Cromwell, E., Friis-Hansen, E., and Turner, M. (1992). The Seed Sector in Developing Countries: A Framework for Performance Analysis. London: Overseas Development Institute.

Cromwell, E., Wiggins, S., and Wentzel, S. (1993). Sowing Beyond the State: NGOs and Seed Supply in Developing Countries. London: Overseas Development Institute (ODI). Available online at: https://cdn.odi.org/media/documents/ 8153.pdf

Dalle, S. P., and Walsh, S. (2015). "USC Canada's experiance in supporting community seed banks in Africa, Asia and the Americas," in Community Seed Banks: Origins, Evolution and Prospects, eds R. Vernooy, P. Shrestha, and B. Sthapit (London: Routledge), 212-230.

de Boef, W. S., Dempewolf, H., Byakweli, J. M., and Engels, J. M. M. (2010). Integrating genetic resource conservation and sustainable development into strategies to increase the robustness of seed systems. J. Sustain. Agric. 34, 504-531. doi: 10.1080/10440046.2010.484689

Demeulenaere, E., and Piersante, Y. (2020). In or out? Organisational dynamics within European 'peasant seed' movements facing opening-up institutions and policies. J. Peasant Stud. 47, 767-791. doi: 10.1080/03066150.2020.1753704

Diriba, G. (2018). Overcoming Agricultural and Food Crises in Ethiopia: Institutional Evolution and the Path to Agricultural Transformation. Printed in the United States of America: Imprint: Independently published.

Elliott, D. A. (1957). Role of agricultural education in the development of agriculture in Ethiopia. etrospective Theses and Dissertations (Retrospective Thesis and PhD Dissertations). Iowa State University (then Iowa State College). Ames, IA. Available online at: https://lib.dr.iastate.edu/rtd/1348

Ellis, F., and Biggs, S. (2001). Evolving themes in rural development 1950s-2000s. Dev. Policy Rev. 19, 437-448. doi: 10.1111/1467-7679.00143

EPA (1997). National Conservation Strategy of Ethiopia. Addis Ababa: Environment Protection Authority (EPA).

FAO (1984). Seed Improvement and Development Programme (SIDP), Ethiopia. Rome: Plant Production and Protection Division of UN-FAO.

FAO (2006). Quality Declared Seed (QDS) System. Rome: Food and Agriculture Organization of the United Nations (FAO). Available online at: http://www.fao. org/plant-treaty/tools/toolbox-for-sustainable-use/details/en/c/1071259/

FAO (2020). National Community Seed Bank Platform for Strengthening Informal Seed System in Ethiopia. Benefit Sharing Fund Project - Fourth Cycle. Food and Agriculture Organization of the United Nations (FAO). Available online at: http://www.fao.org/plant-treaty/areas-of-work/benefitsharing-fund/projects-funded/bsf-details/en/c/1198833/?iso3=ETH (accessed November 2, 2020).

FDRE (1995). Proclamation of the Constitution of the Federal Democratic Republic of Ethiopia. Negarit Gazeta No. 25. Addis Ababa: Negarit Gazeta of the Federal Democratic Republic of Ethiopia (FDRE), 1-38. 
FDRE (1997). Proclamation to Establish Ethiopian Institute of Agricultural Research Proclamation No. 79/1997. Federal Negarit Gazette No. 42. Addis Ababa, Ethiopia: Negarit Gazeta of the Federal Democratic Republic of Ethiopia (FDRE), 529-533.

FDRE (2006). A Proclamation to provide for Access to Genetic Resources and Community Knowledge, and Community Rights. Federal Negarit Gazeta No. 58. Addis Ababa: Negarit Gazeta of the Federal Democratic Republic of Ethiopia (FDRE), 3353-3373.

FDRE (2009). Council of Ministers Regulation to provide for Access to Genetic Resources and Community Knowledge, and Community Rights. Federal Negarit Gazeta No. 67. Addis Ababa: Negarit Gazeta of the Federal Democratic Republic of Ethiopia (FDRE), 5071-5088.

FDRE (2010). Council of Ministers Regulation to Provide for the Establishment of Agricultural Transformation Council and Agency. Regulation No. 198/2010. Federal Negarit Gazeta No. 20. Addis Ababa: Negarit Gazeta of the Federal Democratic Republic of Ethiopia (FDRE).

FDRE (2012). Agricultural Cooperatives Sector Development Strategy 2012-2016. Addis Ababa: Federal Democratic Republic of Ethiopia; MoANR; The Federal Cooperative Agency (FAC); Agricultural Transformation Agency (ATA), 84.

FDRE (2013a). Council of Ministers Regulation to Establish Ethiopian Biodiversity Institute (EBI). Federal Negarit Gazeta No. 57. Addis Ababa: Negarit Gazeta of the Federal Democratic Republic of Ethiopia (FDRE), 6976-6981.

FDRE (2013b). A Proclamation on Seed. Proclamation No. 782/2013. Federal Negarit Gazette No. 27. Addis Ababa: Negarit Gazeta of the Federal Democratic Republic of Ethiopia (FDRE), 6808-6825.

FDRE (2015a). Ethiopian Agricultural Businesses Corporation Establishment Council of Ministers Regulation No. 368/2015. Federal Negarit Gazeta No. 20. Addis Ababa: Negarit Gazeta of the Federal Democratic Republic of Ethiopia (FDRE), 8720-8724.

FDRE (2015b). A Proclamation to amend Biosafety Proclamation. Federal Negarit Gazette No. 66. Addis Ababa: Negarit Gazeta of the Federal Democratic Republic of Ethiopia (FDRE), 8308-8317.

FDRE (2016). Regulation on seed. Council of Ministers Regulation No. 375/2016. Federal Negarit Gazeta No. 42. Addis Ababa: Negarit Gazeta of the Federal Democratic Republic of Ethiopia (FDRE).

FDRE (2017). Plant Breeder's Right Proclamation. Proclamation No. 1068/2017. Negarit Gazeta of the Federal Democratic Republic of Ethiopia (pp. 1028110302). Addis Ababa: Negarit Gazeta of the Federal Democratic Republic of Ethiopia (FDRE).

Fernandez-Cornejo, J. (2004). The Seed Industry in US Agriculture: An Exploration of Data and Information on Crop Seed Markets, Regulation, Industry Structure, and Research and Development. Washington: U.S. Department of Agriculture.

Feyissa, D. (2011). Aid negotiation: the uneasy "partnership" between EPRDF and the donors. J. Eastern Afr. Stud. 5, 788-817. doi: 10.1080/17531055.2011.642541

Feyissa, R., Gezu, G., Tsegaye, B., and Desalegn, T. (2013). "On-farm management of plant genetic resources through community seed banks in Ethiopia," in Community Biodiversity Management- Promoting Resilience and the Conservation of Plant Genetic Resources, eds W. S. de Boef, A. Subedi, N. Peroni, M. Thijssen, and E. O’Keeffe (New York, NY: Routledge), 26-31.

Gebre Egziabher, T. B., Matos, E., and Mwila, G. (2011). "The African regional group: creating fair play between north and south," in Plant Genetic Resources Food Security. Stakeholder Perspectives on the International Treaty on Plant Genetic Resources for Food Agriculture, eds C. Frison, F. López, and J. T. Esquinas-Alcázar (London: Earthscan), 41-56.

Gebre-Egziabher, T. (2014). "Decentralization with regional and local development: trends and policy implications," in Reflections on Development in Ethiopia: New Trends, Sustainability and Challenges, eds D. Rahmato, M. Ayenew, A. Kefale, and B. Habermann (Addis Ababa: Forum for Social Studies and Friedrich Ebert Foundation), 133-167.

Gebreselassie, S. (2006). Intensification of Smallholder Agriculture in Ethiopia: Options and Scenarios. Brighton: Future Agricultures Consortium, Institute of Development Studies, University of Sussex.

Geels, F. W. (2004). From sectoral systems of innovation to socio-technical systems: insights about dynamics and change from sociology and institutional theory. Res. Policy 33, 897-920. doi: 10.1016/j.respol.2004.01.015

Geleti, D. (2020). Revitalizing the Socio-Technical Transition of Ethiopian Agriculture: Rethinking it the 'Medemer' Way. Addis Ababa: Ethiopian Institute of Agricultural Research (EIAR).
Ghose, A. K. (1985). Transforming feudal agriculture: Agrarian change in Ethiopia since 1974. J. Dev. Stud. 22, 127-149. doi: 10.1080/00220388508421972

Gotor, E., Fadda, C., and Trincia, C. (2014). Matching Seeds to NeedsFemale Farmers Adapt to a Changing Climate in Ethiopia. Rome: Bioversity International.

Groosman, T., Linnemann, A. R., and Wierema, H. (1991). Seed Industry Development in a North-South Perspective. Wageningen: Pudoc, Centre for Agricultural Publishing and Documentation.

Hailemichael, S., and Haug, R. (2020). The use and abuse of the 'model farmer' approach in agricultural extension in Ethiopia. J. Agric. Educ. Extension 26, 465-484. doi: 10.1080/1389224X.2020.1757475

Harbeson, J. W. (1977). Socialism, traditions, and revolutionary politics in contemporary Ethiopia. Can. J. Afr. Stud. 11, 217-234. doi: 10.1080/00083968.1977.10803772

Harlan, J. R. (1969). Ethiopia: a center of diversity. Econ. Bot. 23, 309-314. doi: $10.1007 / \mathrm{BF} 02860676$

Harlan, J. R., and de Wet, J. M. J. (1976). "Plant domestication and indigenous African agriculture," in Origins of African Plant Domestication, eds J. R. Harlan, J. M. J. d. Wet, and A. B. L. Stemler (The Hague: De Gruyter Mouton), 3-19.

Harriet, F., and Philip, M. (1989). Agriculture and the state system. The rise and decline of national agricultures. Sociol. Ruralis 29, 93-117. doi: 10.1111/j.1467-9523.1989.tb00360.x

Highfield, J. B. (2017). Food and Foodways in African Narratives: Community, Culture, and Heritage. Oxford: Routledge, Taylor \& Francis Group.

Holtzman, J., Reichhuber, A., and Woelcke, J. (2020). Independent Evaluation of Agra's Policy Project - The Micro Reforms for African Agribusiness (MIRA) Project. Accra: Alliance for a Green Revolution in Africa (AGRA).

IBC (2007). Ethiopia: Second Country Report on the State of Plant Genetic Resources for Food and Agriculture to FAO. Addis Ababa: IBC.

ICARDA (2009). Africa and ICARDA. Aleppo, Syria: International Center for Agricultural Research in the Dry Areas (ICARDA). Available online at: https:// repo.mel.cgiar.org/handle/20.500.11766/7881

IPES-Food (2016). From Uniformity to Diversity: A Paradigm Shift From Industrial Agriculture to Diversified Agroecological Systems. Brussels: IPES-Food.

Jakobsen, J. (2021). New food regime geographies: scale, state, labor. World Dev. 145:105523. doi: 10.1016/j.worlddev.2021.105523

James, C., and Krattiger, A. (1996). Global Review of the Field Testing and Commercialization of Transgenic Plants, 1986 to 1995: The First Decade of Crop Biotechnology. Ithaca, NY: The International Service for the Acquisition of Agri-biotech Applications (ISAAA). Available online at: https://www.isaaa. $\mathrm{org} /$ resources/publications/briefs/01/download/isaaa-brief-01-1996.pdf

Joughin, J. (2014). The Political Economy of Seed Reform in Uganda: Promoting a Regional Seed Trade Market. Washington, D.C.: World Bank. Available online at: https://openknowledge.worldbank.org/handle/10986/17604

Kansiime, M. K., and Mastenbroek, A. (2016). Enhancing resilience of farmer seed system to climate-induced stresses: insights from a case study in West Nile region, Uganda. J. Rural Stud. 47, 220-230. doi: 10.1016/j.jrurstud.2016.08.004

Karim, M. B. (1985). Rural development projects-Comilla, Puebla, and Chilalo: a comparative assessment. Stud. Comp. Int. Dev. 20, 3-41. doi: $10.1007 / \mathrm{BF} 02717354$

Keller, E. J. (1991). Revolutionary Ethiopia: From Empire to People's Republic. Bloomington: Indiana University Press.

Keller, E. J. (1992). Drought, war, and the politics of famine in Ethiopia and Eritrea. J. Mod. Afr. Stud. 30, 609-624. doi: 10.1017/S0022278X00011071

Ker, A. D. R. (1979). Food or Famine: An Account of the Crop Science Program Supported by the International Development Research Centre. Ottawa, ON: International Development Research Centre (IDRC).

Kibsgaard, D. (2020). Sino-Ethiopian relations from meles zenawi to abiy ahmed: the political economy of a strategic partnership. China Curr. 19. Available online at: https://www.chinacenter.net/2020/china_currents/19-2/ sino-ethiopian-relations-from-meles-zenawi-to-abiy-ahmed-the-politicaleconomy-of-a-strategic-partnership/

Kloppenburg, J. R. (2004). First the Seed: The Political Economy of Plant Biotechnology 1492-2000, 2nd Edn. Madison, WI: University of Wisconsin Press.

Kuyek, D. (2007). Sowing the seeds of corporate agriculture: the rise of Canada's third seed regime. Stud. Polit. Econ. 80, 31-54. doi: $10.1080 / 19187033.2007 .11675082$ 
Leach, M., Nisbett, N., Cabral, L., Harris, J., Hossain, N., and Thompson, J. (2020). Food politics and development. World Dev. 134:105024. doi: 10.1016/j.worlddev.2020.105024

Lefort, R. (2012). Free market economy, 'developmental state' and party-state hegemony in Ethiopia: the case of the 'model farmers'. J. Mod. Afr. Stud. 50, 681-706. doi: 10.1017/S0022278X12000389

Louwaars, N. P., and de Boef, W. S. (2012). Integrated seed sector development in Africa: a conceptual framework for creating coherence between practices, programs, and policies. J. Crop Improvement 26, 39-59. doi: 10.1080/15427528.2011.611277

Louwaars, N. P., de Boef, W. S., and Edeme, J. (2013). Integrated seed sector development in Africa: a basis for seed policy and law. J. Crop Improvement 27, 186-214. doi: 10.1080/15427528.2012.751472

Lyon, A., Friedmann, H., and Wittman, H. (2021). Can public universities play a role in fostering seed sovereignty? Elementa Sci. Anthropocene 9:00089. doi: 10.1525/elementa.2021.00089

Mayet, M. (2015). Seed Sovereignty in Africa: challenges and opportunities. Development 58, 299-305. doi: 10.1057/s41301-016-0037-x

McCann, J. (2005). Maize and Grace: Africa's Encounter With the New World, 1500-2000. Cambridge: Harvard University Press.

McCann, J. C. (1990). A great agrarian cycle? Productivity in highland Ethiopia, 1900 to 1987. J. Interdiscipl. History 20, 389-416. doi: 10.2307/204084

McCann, J. C. (1995). People of the Plow: An Agricultural History of Ethiopia, 1800-1990. London: University of Wisconsin Press.

McCann, J. C. (2011). The political ecology of cereal seed development in Africa: a history of selection. IDS Bull. 42, 24-35. doi: 10.1111/j.1759-5436.2011. 00233.x

McGuire, S. (2007). Vulnerability in farmer seed systems: farmer practices for coping with seed insecurity for sorghum in Eastern Ethiopia. Econ. Bot. 61, 211-222. doi: 10.1663/0013-0001(2007)61[211:VIFSSF]2.0.CO;2

McGuire, S., and Sperling, L. (2016). Seed systems smallholder farmers use. Food Security 8, 179-195. doi: 10.1007/s12571-015-0528-8

McVety, A. K. (2008). Pursuing progress: point four in Ethiopia. Diplomatic History 32, 371-403. doi: 10.1111/j.1467-7709.2008.00698.x

McVety, A. K. (2012). Enlightened Aid: US Development as Foreign Policy in Ethiopia. Oxford; New York, NY: Oxford University Press.

MoA (2019). Transforming the Ethiopian Seed Sector: Issues and Strategies. Addis Ababa: Ministry of Agriculture (MoA). Available online at: https:// issdethiopia.org/2019/11/22/transforming-the-ethiopian-seed-sector-issuesand-strategies/

MoA and ATA (2015). Quality Declared Seeds Directive. No. 1/2007 (in Amharic). Addis Ababa: Ministry of Agriculture(MoA); Agricultural Transformation Agency (ATA).

MoA and ATA (2017). Seed System Development Strategy: Vision, systematic challenges, and prioritized interventions. Working Strategy Document. Addis Ababa: Ministry of Agriculture (MoA); Agricultural Transformation Agency (ATA).

Mockshell, J., and Birner, R. (2015). Donors and domestic policy makers: two worlds in agricultural policy-making? Food Policy 55, 1-14. doi: 10.1016/j.foodpol.2015.05.004

Mulesa, T. H., Dalle, S. P., Makate, C., Haug, R., and Westengen, O. T. (2021). Pluralistic seed system development: a path to seed security? Agronomy 11:372. doi: 10.3390/agronomy11020372

Mulesa, T. H., and Westengen, O. T. (2020). Against the grain? A historical institutional analysis of access governance of plant genetic resources for food and agriculture in Ethiopia. J. World Intellectual Property 23, 82-120. doi: 10.1111 /jwip. 12142

Murdock, G. P. (1960). Staple subsistence crops of Africa. Geogr. Rev. 50, 523-540. doi: $10.2307 / 212308$

National Research Council (1996). Lost Crops of Africa: Volume I: Grains. Washington, DC: The National Academies Press.

North, D. C. (1990). Institutions, Institutional Change and Economic Performance. Cambridge: Cambridge University Press.

O'Connor Funk, A. (ed.). (2009). The African seed Company Toolbox: 52 Tools every Seed Company Manager Should Know How to Use. Nairobi: Bill \& Melinda Gates Foundation.

Odame, H., and Muange, E. (2011). Can agro-dealers deliver the green revolution in Kenya? IDS Bull. 42, 78-89. doi: 10.1111/j.1759-5436.2011.00238.x
Ojo, M. O., and Ramtoolah, T. (2000). Ethiopia: Structural Adjustment Programme Project Performance Evaluation Report (PPER). Abidjan: Operations Evaluation Department, African Development Bank Group.

Otieno, G. A., Reynolds, T. W., Karasapan, A., and Noriega, I. L. (2017). Implications of seed policies for on-farm agro-biodiversity in Ethiopia and Uganda. Sustain. Agric. Res. 6, 12-30. doi: 10.5539/sar.v6n4p12

Patel, R. (2009). Food sovereignty. J. Peasant Stud. 36, 663-706. doi: $10.1080 / 03066150903143079$

Pistorius, R. (1997). Scientists, Plants and Politics: A History of the Plant Genetic Resources Movement. Rome: International Plant Genetic Resources Institute/Bioversity International.

PMAC (1975). A Proclamation to Provide for the Public Ownership of Rural Lands. Proclamation No. 31/1975, 93-101, Addis Ababa: Nagaret Gazeta.

Rameshshanker, V., MacIntyre, C., and Stewart, S. (2020). Beyond the Headlines: Forgotten Fragility in Ethiopia. Ottawa, ON: Norman Paterson School of International Affairs, Carleton University. Available online at: https://reliefweb. int/sites/reliefweb.int/files/resources/Ethiopia-Fragility-Brief-2021.pdf

Rohne Till, E. (2020). A green revolution in sub-Saharan Africa? The transformation of Ethiopia's agricultural sector. J. Int. Dev. 33, 277-315. doi: $10.1002 /$ jid. 3523

Rubenson, S. (1961). Some Aspects of the Survival of Ethiopian Independence in the Period of the Scramble for Africa, Vol. 1. University College Review, 8-24. Available online at: http://www.jstor.org/stable/41965666

Rusike, J. (1995). An Institutional Analysis of the Maize Seed Industry in Southern Africa. Michigan State University, East Lansing, MI. Available online at: https:// d.lib.msu.edu/etd/25727/datastream/OBJ/View/

Rusike, J., and Donovan, P. A. (1996). The evolution of the maize seed industry in Zambia. Dev. South. Afr. 13, 109-117. doi: 10.1080/03768359608439878

Scoones, I., and Thompson, J. (2009). Farmer First Revisited: Innovation for Agricultural Research and Development. Rugby: Technical Centre for Agricultural and Rural Cooperation, Practical Action.

Scoones, I., and Thompson, J. (2011). The politics of seed in Africa's green revolution: alternative narratives and competing pathways. IDS Bull. 42, 1-23. doi: $10.1111 / j .1759-5436.2011 .00232 . x$

Simane, B. (2008). "Seed policies and regulations and informal seed supply in Ethiopia," in Farmers, Seeds Varieties: Supporting Informal Seed Supply in Ethiopia, eds M. H. Thijssen, Z. Bishaw, A. Beshir, and W. S. De Boef (Wageningen: Wageningen International), 312-316.

Sisay, D. T., Verhees, F. J. H. M., and van Trijp, H. C. M. (2017). Seed producer cooperatives in the Ethiopian seed sector and their role in seed supply improvement: a review. J. Crop Improvement 31, 323-355. doi: 10.1080/15427528.2017.1303800

Spielman, D. J., Byerlee, D., Alemu, D., and Kelemework, D. (2010). Policies to promote cereal intensification in Ethiopia: the search for appropriate public and private roles. Food Policy 35, 185-194. doi: 10.1016/j.foodpol.2009.12.002

Spielman, D. J., Mekonnen, D. K., and Alemu, A. D. (2012). "Seed, fertilizer, and agricultural extension in Ethiopia," in Food and Agriculture in Ethiopia: Progress and Policy Challenges, Vol. 74, eds P. Dorosh and S. Rashid (Philadelphia, PA: University of Pennsylvania Press), 84-122.

Ståhl, M. (1973). Contradictions in Agricultural Development: A Study of Three Minimum Package Projects in Southern Ethiopia (Research Report No. 14). Uppsala: Nordiska Afrikainstitutet.

Stommes, E., and Sisaye, S. (1979a). The administration of agricultural development programmes: a look at the Ethiopian approach-Part 1. Agric. Administr. 6, 221-239.

Stommes, E., and Sisaye, S. (1979b). The administration of agricultural development programmes: a look at the Ethiopian approach-Part 2. Agric. Administr. 6, 253-267.

Sumberg, J., Thompson, J., and Woodhouse, P. (2019). "Political agronomy," in Encyclopedia of Food and Agricultural Ethics, ed D. M. Kaplan (Dordrecht: Springer Netherlands), 2007-2014.

Sumberg, J. E., Thompson, J., and Woodhouse, P. (2012). "Contested agronomy: agricultural research in a changing world. Introduction," in Pathways to Sustainability Series, 1st Edn., eds J. E. Sumberg and J. Thompson (New York, NY: Routledge), 1-21.

Tansey, G. (2011). Whose Power to Control? Some reflections on seed systems and food security in a changing world. ids Bull. 42, 111-120. doi: 10.1111/j.1759-5436.2011.00241.x 
Teklu, Y., and Hammer, K. (2006). Farmers' perception and genetic erosion of tetraploid wheats landraces in Ethiopia. Genet. Resour. Crop Evol. 53, 1099-1113. doi: 10.1007/s10722-005-1145-8

Thijssen, M. H., Bishaw, Z., Beshir, A., and de Boef, W. S. (eds.). (2008). Farmers, Seeds and Varieties: Supporting Informal Seed Supply in Ethiopia. Wageningen: Wageningen International.

Thijssen, M. H., Borman, G. D., Verhoosel, K. S., Mastenbroek, A., and Heemskerk, W. (2015). "Local seed business in the context of Integrated Seed Sector Development Community Seed Production," in Workshop Proceedings, 9-11 December 2013 (Rome).

Thompson, J., and Scoones, I. (2009). Addressing the dynamics of agri-food systems: an emerging agenda for social science research. Environ. Sci. Policy Sci. 12, 386-397. doi: 10.1016/j.envsci.2009.03.001

Timothy, D. H., Harvey, P. H., and Dowswell, C. R. (1988). Development and Spread of Improved Maize Varieties and Hybrids in Developing Countries. Washington: Bureau for Science and Technology; Agency for International Development and CIMMYT.

Tripp, R., Louwaars, N., and Eaton, D. (2007). Plant variety protection in developing countries. A report from the field. Food Policy 32, 354-371. doi: 10.1016/j.foodpol.2006.09.003

Truman, H. S. (1949). Truman's Inaugural Address. Available online at: http:// www.presidency.ucsb.edu/ws/?pid=13282

Tschersich, J. (2021). Norm conflicts as governance challenges for seed commons: comparing cases from Germany and the Philippines. Earth System Governance 7:100097. doi: 10.1016/j.esg.2021.100097

Vaughan, S., and Tronvoll, K. (2003). The Culture of power in Contemporary Ethiopian Political Life. Stockholm: Swedish International Development Cooperation Agency.

Vavilov, N. I. (1992). Origin and Geography of Cultivated Plants (V. F. Dorofeyev, ed. 1st Edn.). Cambridge: Cambridge University Press.

Velissariou, J. V. (1954). The economy of Ethiopia (Master Thesis). Boston University, Boston, MA, United States. Available online at: https://hdl.handle. net/2144/8739

Walsh, D., and Dahir, A. L. (2021). Why Is Ethiopia at War With Itself? Available online at: https://www.nytimes.com/2020/11/05/world/africa/ethiopia-tigrayconflict-explained.html

Westengen, O. T. (2017). "Crops in context: negotiating traditional and formal seed institutions," in Agronomy for Development: The Politics of Knowledge in Agricultural Research, ed J. Sumberg (London; New York, NY: Routledge Taylor \& Francis Group), 15.

Westengen, O. T., and Banik, D. (2016). The state of food security: from availability, access and rights to food systems approaches. Forum Dev. Stud. 43, 113-134. doi: 10.1080/08039410.2015.1134644

Westengen, O. T., Haug, R., Guthiga, P., and Macharia, E. (2019). Governing seeds in East Africa in the face of climate change: assessing political and social outcomes. Front. Sustain. Food Syst. 3:53. doi: 10.3389/fsufs.2019.00053

Westengen, O. T., Skarb,ø, K., Mulesa, T. H., and Berg, T. (2018). Access to genes: linkages between genebanks and farmers' seed systems. Food Security 10, 9-25. doi: 10.1007/s12571-017-0751-6

Westphal, E. (1975). Agricultural Systems in Ethiopia. Wageningen: Centre for Agricultural Publishing and Documentation

Woldemariam, W. (1990). The Role of the Ethiopian Seed Corporation in the Multiplication and Distribution of Seed of Improved Wheat Varieties in Ethiopia.
Sixth Regional Wheat Workshop for Eastern (Addis Ababa: Central and Southern Africa).

Woolfrey, S., Bizzotto Molina, P., and Ronceray, M. (2021). AgrInvest-Food Systems Project-Political Economy Analysis of the Ethiopian Food System: Key Political Economy Factors and Promising Value Chains to Improve Food System Sustainability. Rome: Food and Agricultural Organization of the United Nations (FAO). Available online at: http://www.fao.org/documents/card/en/c/ cb3255en

Worede, M. (1991). "An Ethiopian perspective on conservation and utilization of plant genetic resources," in Plant Genetic Resources of Ethiopia, eds J. M. M. Engels, J. G. Hawkes, and M. Worede (Cambridge; New York, NY: Cambridge University Press), 1-21.

Worede, M. (1992). "Ethiopia: a genebank working with farmers," in Growing Diversity, Genetic Resources and Local Food Security, eds D. Cooper, R. Vellve, and H. Hobbelink (London: Intermediate Technology Publications), 78-94.

Worede, M. (1997). "Ethiopian in situ conservation," in Plant Genetic Conservation: The in situ Approach, eds N. Maxted, B. V. Ford-Lloyd, and J. G. Hawkes (Dordrecht: Springer Netherlands), 290-301.

World Bank (1980). Ethiopia - Second Agricultural Minimum Package Project. Available online at: http://documents.worldbank.org/curated/en/ 665331468275118901/Ethiopia-Second-Agricultural-Minimum-PackageProject

World Bank (1998). Implementation Completion Report, Ethiopia, Emergency Recovery and Reconstruction Project (Credit 2351-ET). Washington, DC: The World Bank Group. Available online at: http://documents1.worldbank.org/ curated/en/800591468023078407/text/multi-page.txt

World Bank (2003). Seed Systems Development Project: Seed Systems Development Project. Washington, DC: The World Bank.

Yemane-ab, A. (2016). "Land to the tiller": unrealized agenda of the revolution. Northeast Afr. Stud. 16, 39-64. doi: 10.14321/nortafristud.1 6.1 .0039

Ylönen, A. (2021). Counting on friends in tigray: internal and regional considerations in the ongoing crisis. HORN Bull. 4, 1-13. Available online at: https://horninstitute.org/the-horn-bulletins/

Conflict of Interest: The author declares that the research was conducted in the absence of any commercial or financial relationships that could be construed as a potential conflict of interest.

Publisher's Note: All claims expressed in this article are solely those of the authors and do not necessarily represent those of their affiliated organizations, or those of the publisher, the editors and the reviewers. Any product that may be evaluated in this article, or claim that may be made by its manufacturer, is not guaranteed or endorsed by the publisher.

Copyright (C) 2021 Mulesa. This is an open-access article distributed under the terms of the Creative Commons Attribution License (CC BY). The use, distribution or reproduction in other forums is permitted, provided the original author(s) and the copyright owner(s) are credited and that the original publication in this journal is cited, in accordance with accepted academic practice. No use, distribution or reproduction is permitted which does not comply with these terms. 